\title{
Carbonate Precipitation through Microbial Activities in Natural Environment, and Their Potential in Biotechnology: A Review
}

\author{
Tingting Zhu and Maria Dittrich* \\ Department of Physical and Environmental Sciences, University of Toronto Scarborough, Toronto, ON, Canada
}

Calcium carbonate represents a large portion of carbon reservoir and is used commercially for a variety of applications. Microbial carbonate precipitation, a by-product of microbial activities, plays an important metal coprecipitation and cementation role in natural systems. This natural process occurring in various geological settings can be mimicked and used for a number of biotechnologies, such as metal remediation, carbon sequestration, enhanced oil recovery, and construction restoration. In this study, different

OPEN ACCESS

Edited by: Weiwen Zhang,

Tianjin University, China

Reviewed by:

Kesaven Bhubalan,

Universiti Malaysia Terengganu,

Malaysia

Alan W. Decho,

University of South Carolina, USA

${ }^{*}$ Correspondence:

Maria Dittrich

mdittrich@utsc.utoronto.ca

Specialty section:

This article was submitted to Microbiotechnology, Ecotoxicology and Bioremediation,

a section of the journal

Frontiers in Bioengineering and

Biotechnology

Received: 30 November 2015 Accepted: 07 January 2016

Published: 20 January 2016

Citation:

Zhu T and Dittrich M (2016) Carbonate Precipitation through

Microbial Activities in Natural Environment, and Their Potential in

Biotechnology: A Review.

Front. Bioeng. Biotechnol. 4:4. doi: 10.3389/fbioe.2016.00004 metabolic activities leading to calcium carbonate precipitation, their native environment, and potential applications and challenges are reviewed.

Keywords: microbial carbonate precipitation, metabolisms, natural environment, biotechnology, challenges

\section{INTRODUCTION}

Carbonates in the form of limestone and dolomite represent an important carbon reservoir, accounting for $41.9 \%$ of the total carbon on Earth (Ehrlich, 1996). At the Earth's surface, a significant portion of the insoluble carbonate is of biogenic origin, involving bacteria, fungi, algae, and metazoa (Gadd, 2010). The involvement of microorganisms in the massive precipitation of calcium carbonates is well illustrated by stromatolites (Grotzinger and Knoll, 1999) and whiting events (Thompson et al., 1997). Microbial carbonate precipitation (MCP) can occur as a by-product of common microbial metabolic activities, including photosynthesis (Dupraz et al., 2004), ureolysis (Fujita et al., 2000), denitrification (Van Paassen et al., 2010), ammonification (Rodriguez-Navarro et al., 2003), sulfate reduction (Braissant et al., 2007), and methane oxidation (Reeburgh, 2007). In addition, cell walls and extracellular polymeric substances (EPS) are reported to serve as templates for carbonate precipitation (Obst et al., 2009).

A stunningly diverse collection of microbial species is nurtured by a variety of environmental conditions. MCP is an ubiquitous process that plays an important role in the cementation of natural systems, such as caves, soils, sediments, aquifers, and open-water areas (Riding, 2000; Banks et al., 2010; Chou et al., 2011). Inspired by its natural capability to coprecipitate metal ions, cement sands/ soils/minerals, and sequestrate $\mathrm{CO}_{2}, \mathrm{MCP}$ is proposed to be a promising technology in metal remediation, soil reinforcement, enhanced oil recovery (EOR), and construction restoration (Dejong et al., 2006; Sen, 2008; Bang et al., 2010; Achal et al., 2012).

Although successful technological applications of MCP have been demonstrated in the laboratory, challenges still exist regarding upscaling these processes to the field scale, and managing the treatment of by-products (De Jong et al., 2013). Few studies have attempted to identify the environmental factors that exert the strongest influences on microbial communities, which are most diverse and 
abundant on Earth (Fierer and Jackson, 2006). Compared with the experimental conditions in the laboratory, those of the fields are much more complex and interfered with each other, hence exerting more inhibitions and triggers on microbial growth and metabolic activities.

A majority of the studies on biotechnology using MCP, especially in metal remediation, microbial enhanced oil recovery (MEOR), and construction restoration, are based on ureolysis (De Muynck et al., 2013; Kumari et al., 2014). However, ureolytic bacteria are not ubiquitous, considering specific environmental conditions. In many applications, their growth or metabolic activities are inhibited, and in other cases, they are not able to survive (Dhami et al., 2013; Phillips et al., 2013; Achal and Mukherjee, 2015). Therefore, alternative microbial communities leading to calcium carbonate precipitation should be suggested and considered for the best option of engineering projects.

This study reviews different microbial activities related to calcium carbonate precipitation, their occurrence in various geological settings, the application fields of MCP biotechnology, and the challenges for the real applications. A relationship between metabolic pathways and environmental conditions is established, its indication for the potential application is presented, challenges related to different engineering projects are identified, and strategies to mitigate those challenges are proposed.

\section{MICROBIAL CARBONATE PRECIPITATION BY DIFFERENT MICROBIAL ACTIVITIES IN NATURAL ENVIRONMENTS}

In nature, a variety of microorganisms is known to induce carbonate precipitation by altering solution chemistry through a wide range of physiological activities (Castanier et al., 1999; Riding, 2000; Dejong et al., 2010; Maignien et al., 2011; De Muynck et al., 2013), or by serving as a crystal nucleus (Aloisi et al., 2006). In marine and freshwater systems, photosynthetic microbes are responsible for triggering calcite precipitation (Arp et al., 2001; Dittrich and Obst, 2004; Plée et al., 2010), whereas in a wide variety of environments, consortia with both phototrophs (e.g., cyanobacteria and microalgae) and heterotrophs mediate the calcite precipitation (Power et al., 2011). Microorganisms induce carbonate precipitation through different metabolic pathways, such as photosynthesis, ureolysis, ammonification, denitrification, sulfate reduction, anaerobic sulfide oxidation, and methane oxidation, either increasing $\mathrm{pH}$ or dissolved inorganic carbon (DIC) (Table 1). Furthermore, most microbial cells provide nucleation sites for carbonate formation. Inspired by their precipitation potential in nature, several biotechnologies related to MCP have been proposed (Whiffin et al., 2007; Fujita et al., 2008; De Belie and De Muynck, 2009; Bang et al., 2010).

The importance of the MCP is reflected in the tremendous amount of publications, and some studies have tested MCP for the real applications. In the database Web of Science, the search topic ("carbonate precipitation" OR "calcite precipitation" OR calcification) AND (microb* OR microorganisms) shows 8412 results (Figure 1). Adding one more keyword - "technology" - to the search, results in 75 articles. Replacing the keyword (microb* OR microorganisms) with photosynth ${ }^{\star}$, ureoly ${ }^{\star}$, denitrification, ammonification, "sulfate reduction," and "methane oxidation," the number of the articles is $1128,120,34,5,110$, and 44 , respectively. It indicates that the mostly studied calcification processes in the natural environment are through photosynthesis and ureolysis. By adding "technology" to each of them, it results in 13, 19, 3, 1,2 , and 0 articles instead. It shows that ureolysis is the most developed technology among other metabolisms, followed by photosynthesis. Although "sulfate reduction" is widely studied, it is less likely to be taken advantage of in the engineering project.

\section{Carbonate Precipitation Induced by Microbes \\ Cell Surfaces and Extracellular Polymeric Substances}

Cell surfaces have been shown as highly effective nucleation templates for carbonate precipitation (Warren et al., 2001). Cell walls with negatively charged functional groups, such as carboxyl, phosphate, and amine, are able to adsorb metal ions (Dittrich and Sibler, 2005; Fein, 2006) (Figure 2A). For example, the cell wall of

TABLE 1 | Reactions and by-products involved in different metabolic pathways leading to MCP.

\begin{tabular}{|c|c|c|c|c|}
\hline Microbial groups & Metabolism & Reference & Reactions & By-product \\
\hline $\begin{array}{l}\text { Cyanobacteria } \\
\text { Algae }\end{array}$ & Photosynthesis & $\begin{array}{l}\text { Baumgartner et al. } \\
\text { (2006) }\end{array}$ & $2 \mathrm{HCO}_{3}^{-}+\mathrm{Ca}^{2+} \rightarrow \mathrm{CH}_{2} \mathrm{O}+\mathrm{CaCO}_{3}+\mathrm{O}_{2}$ & $\begin{array}{l}\mathrm{O}_{2} \\
\mathrm{CH}_{2} \mathrm{O}\end{array}$ \\
\hline Ureolytic bacteria & Ureolysis & $\begin{array}{l}\text { Achal and Mukherjee } \\
\text { (2015) }\end{array}$ & $\mathrm{CO}\left(\mathrm{NH}_{2}\right)_{2}+2 \mathrm{H}_{2} \mathrm{O}+\mathrm{Ca}^{2+}+\mathrm{Cell} \rightarrow 2 \mathrm{NH}_{4}^{+}+\mathrm{Cell}-\mathrm{CaCO}_{3}$ & $\mathrm{NH}_{4}^{+}$ \\
\hline $\begin{array}{l}\text { Nitrate-reducing } \\
\text { bacteria }\end{array}$ & Denitrification & Er冈an et al. (2015b) & $\begin{array}{l}\mathrm{CH}_{2} \mathrm{COO}^{-}+2.6 \mathrm{H}^{+}+1.6 \mathrm{NO}_{3}^{-} \rightarrow 2 \mathrm{CO}_{2}+0.8 \mathrm{~N}_{2}+2.8 \mathrm{H}_{2} \mathrm{O} \\
\mathrm{Ca}^{2+}+\mathrm{CO}_{2}(\mathrm{aq})+2 \mathrm{OH}^{-} \rightarrow \mathrm{CaCO}_{3}(\mathrm{~s})+\mathrm{H}_{2} \mathrm{O}\end{array}$ & $\begin{array}{l}\text { Complete reaction: } \mathrm{CO}_{2}+\mathrm{N}_{2} \\
\text { Incomplete reaction: } \\
\mathrm{NO}+\mathrm{N}_{2} \mathrm{O}\end{array}$ \\
\hline Myxobacteria & Ammonification & $\begin{array}{l}\text { González-Muñoz et al. } \\
\text { (2010) }\end{array}$ & - & $\mathrm{NH}_{3}$ \\
\hline $\begin{array}{l}\text { Sulfate reduction } \\
\text { bacteria }\end{array}$ & $\begin{array}{l}\text { Sulfate } \\
\text { reduction }\end{array}$ & $\begin{array}{l}\text { Baumgartner et al. } \\
\text { (2006) }\end{array}$ & $\mathrm{SO}_{4}^{2-}+2\left[\mathrm{CH}_{2} \mathrm{O}\right]+\mathrm{OH}^{-}+\mathrm{Ca}^{2+} \rightarrow \mathrm{CaCO}_{3}+\mathrm{CO}_{2}+2 \mathrm{H}_{2} \mathrm{O}+\mathrm{HS}^{-}$ & $\begin{array}{l}\mathrm{CO}_{2} \\
\mathrm{HS}^{-}\end{array}$ \\
\hline Methanogens & $\begin{array}{l}\text { Methane } \\
\text { oxidation }\end{array}$ & Reeburgh (2007) & $\begin{array}{l}\text { Anaerobic oxidation: } \mathrm{CH}_{4}+\mathrm{SO}_{4}^{2-}+\mathrm{Ca}^{2+} \rightarrow \mathrm{CaCO}_{3}+\mathrm{H}_{2} \mathrm{~S}+\mathrm{H}_{2} \mathrm{O} \\
\text { Aerobic oxidation: } \mathrm{CH}_{4}+2 \mathrm{O}_{2} \rightarrow \mathrm{CO}_{2}+2 \mathrm{H}_{2} \mathrm{O}\end{array}$ & $\mathrm{H}_{2} \mathrm{~S}$ \\
\hline
\end{tabular}




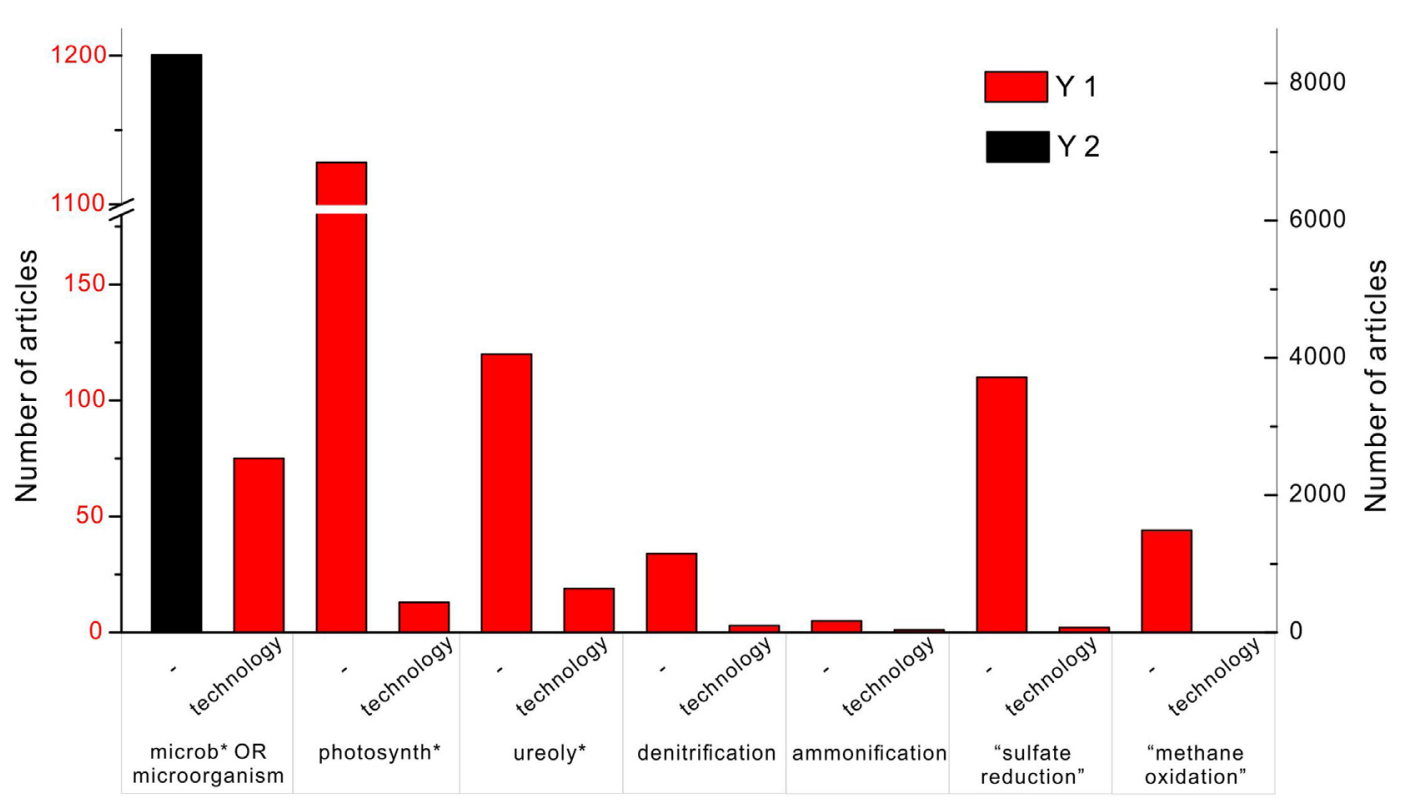

FIGURE 1 | Number of articles on the topic of "carbonate precipitation" OR "calcite precipitation" OR "calcification" in the database of Web of Science of all years. The black column represents the search with an additional keyword "microb* OR microorganisms," and corresponds to the $y$-axis on the right side. The red column indicates the number of publications found with an additional keyword "technology," and corresponds to the $y$-axis on the left showing 75 articles. Among published work, carbonate precipitation induced by photosynthesis, ureolysis, and sulfate reduction are well studied with 1128,120 , and 110 articles, respectively. Technologies of microbial carbonate precipitation are commonly based on photosynthesis and ureolysis, with 13 and 19 articles, respectively.

Bacillus subtilis uptakes a substantial amount of $\mathrm{Mg}^{2+}, \mathrm{Fe}^{3+}, \mathrm{Cu}^{2+}$, $\mathrm{Na}^{+}, \mathrm{K}^{+}, \mathrm{Mn}^{2+}, \mathrm{Zn}^{2+}, \mathrm{Ca}^{2+}, \mathrm{Au}^{3+}$, and $\mathrm{Ni}^{2+}$ (Beveridge and Murray, 1976; Fein et al., 1997). This increases the concentration of the metal ions in the microenvironment, and when bicarbonate or carbonate is available, the oversaturation in respect to carbonates is easily obtained. In a number of studies, this mechanism was found to be behind calcite nucleation on the cell wall of picocyanobacteria (Warren et al., 2001; Kosamu and Obst, 2009).

Extracellular polymeric substances play an important role in microbial calcification as well (Tourney and Ngwenya, 2014), either inhibiting or promoting carbonate precipitation (Dupraz et al., 2009a). Both photoautotrophic and heterotrophic bacteria can produce EPS, although cyanobacteria are recognized as the most important EPS producers (De Philippis et al., 2001). EPS containing various acidic residues and sugars may trap a large amount of divalent cations, such as $\mathrm{Ca}^{2+}$ and $\mathrm{Mg}^{2+}$ (Kremer et al., 2008). Metal binders, such as carboxyl, phosphate, amine, and hydroxyl groups, present in EPS (Tourney et al., 2008; Dittrich and Sibler, 2010) (Figure 2B). EPS remove free cations from solution by binding them to those negatively charged groups. Consequently, EPS reduce the saturation in respect of calcium carbonate and inhibit the precipitation of carbonates precipitation (Dupraz et al., 2009a). After EPS are degraded; however, $\mathrm{Ca}^{2+}$ may locally reach high concentrations and thus favor precipitation of calcium carbonate (Reid et al., 2000; Dupraz and Visscher, 2005). Carbonates can be precipitated on the non-degraded EPS matrix as well, through a continuous supply of cations combined with a local alkaline condition (Arp et al., 1999). Compared to the abiotically precipitated calcium carbonates, the morphology and mineralogy of those formed with the involvement of EPS vary greatly (Tourney and Ngwenya, 2009). Containing various functional groups, EPS significantly influence bacterial adhesion onto solid substratum surfaces (Figure 2) (Neu, 1996; Tsuneda et al., 2003). In addition, EPS improve the cohesion of sediments by gluing the particles in a similar way EPS support forming microbialites (Tourney and Ngwenya, 2014). Microorganisms adhere to substrates either by generic physical-chemical forces, such as van der Waals and electrostatic forces, or by the specific surface structures of the cell, such as pili, fimbriae, or other appendages (Van Loosdrecht et al., 1989). Determined by surface speciation of EPS, the bacterial and mineral surfaces, hydrophobicity, and electrostatic interactions drive the adsorption of bacteria on mineral surfaces (Yee et al., 2000).

\section{Photosynthesis}

Photosynthetic microbes, particularly cyanobacteria, are recognized as being responsible for massive carbonate precipitations. It is estimated that cyanobacteria are the principle contributors to the production of carbonate rocks during almost $70 \%$ of Earth history (Altermann et al., 2006). Cyanobacterial stromatolite, a laminated calcareous fossil, was found in various environments, such as freshwater, marine, and terrestrial areas (Krumbein and Giele, 1979; Wright, 1989; Goh et al., 2010; Rodriguez-Martinez et al., 2012). Whiting events, which turn the entire water bodies into a milky state (Thompson et al., 1997), also show the high potential of calcification by picocyanobacteria.

Photosynthesis leads to calcite precipitation by conducting an $\mathrm{HCO}_{3}^{-} / \mathrm{OH}^{-}$exchange process across the cell membrane, 


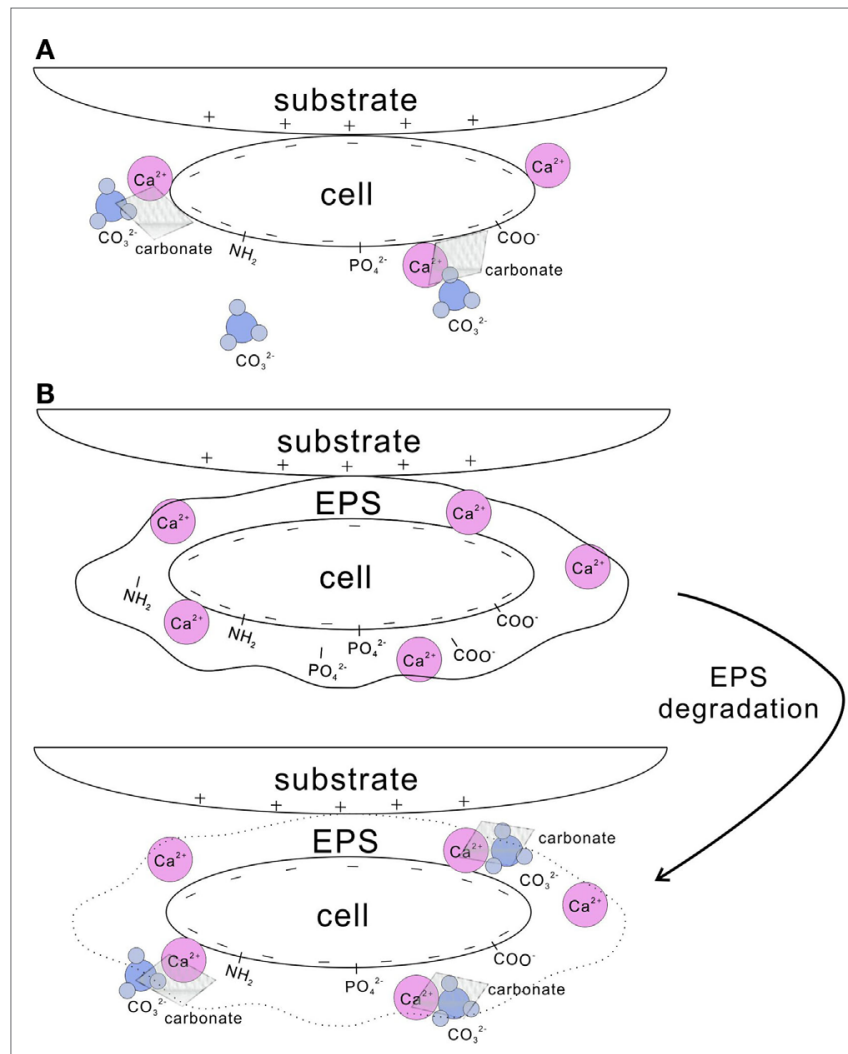

FIGURE 2 | Nucleation of carbonate crystals on microbial surfaces. (A) Cell wall with negatively charged functional groups, such as carboxyl, phosphate, and amine groups, adsorbs $\mathrm{Ca}^{2+}$. Subsequently, carbonates precipitates on the cell surface when carbonate species are available. (B) EPS-containing functional groups trap a large amount of $\mathrm{Ca}^{2+}$. After EPS is degraded, high concentration of $\mathrm{Ca}^{2+}$ is reached locally and results in the precipitation of calcium carbonate in the presence of carbonate species. In addition, cells with negatively charged surface tend to attach to substrates with positive charges.

resulting in an increase of $\mathrm{pH}$ in the microenvironment around cells (Miller and Colman, 1980) (Figure 3). $\mathrm{Na}^{+}$and $\mathrm{HCO}_{3}^{-}$ are transported into cells through a symporter; $\mathrm{CO}_{2}$ enters the cell wall either through this symporter or by diffusion (Espie and Kandasamy, 1992). $\mathrm{CO}_{2}$ is synthesized to form organic matter through photosynthesis, and bicarbonate is converted to $\mathrm{CO}_{2}$ and $\mathrm{OH}^{-}$, the so-called $\mathrm{CO}_{2}$ concentration mechanism. The $\mathrm{OH}^{-}$is then released into the solution, increasing the $\mathrm{pH}$ (Table 1).

As a result of photosynthetic activity, a higher $\mathrm{pH}$ value and the subsequent higher carbonate concentration were measured in illuminated mats than in those measured in dark mats (Ludwig et al., 2005). A mutated-strain modified $\mathrm{CO}_{2}$ concentration mechanism resulted in higher $\mathrm{HCO}_{3}^{-}$uptake than wild-type cells, and an increase of the $\mathrm{pH}$ of the microenvironment around the cells, increasing the calcification process (Jiang et al., 2013). Interestingly, in some cases, cells are able to store excessive $\mathrm{Ca}^{2+}$, precipitate calcium carbonate inside or transport it outside of the cell wall through an antiporter (Waditee et al., 2004).

\section{Ureolysis}

Similar to the photosynthetic microorganisms, ureolytic bacteria impact the concentration of the DIC and the $\mathrm{pH}$ of an environment, yet through urea hydrolysis. For example, Sporosarcina pasteurii (Wei et al., 2015) hydrolyze urea to produce ammonia and carbonic acid (De Muynck et al., 2013) (Figure 3). The subsequent hydrolysis of ammonia increases the $\mathrm{pH}$ by producing $\mathrm{OH}^{-}$, and the dissociation of carbonic acid generates bicarbonates (Knoll, 2003). In this process, alkalinity is increased through urea hydrolysis at a cost of generating the unfavorable by-product ammonia. Therefore, the reaction favors the precipitation of calcium carbonate in the presence of calcium in solution (Table 1).

Urea is a nitrogen source for a variety of microorganisms belonging to different genus or species, including fungi (Aspergillus sp., Coprinus sp., Neurospora sp., Penicillium sp., and Ustilago sp.), Bacillus (Bacillus lentus, B. pasteurii, B. sphaericus, and B. subtilis), Lactobacillus (Lactobacillus reuteri, L. animalsi, L. fermentum, Streptococcus salivarius, S. mitior, S. thermophilus, and Staphylococcus epidermis), Nitrosomonas and Nitrosospira species, purple sulfur and non-sulfur bacteria (Rhodobacter capsulatus), cyanobacteria (Anabaena cycadae, A. cylindrica, A. doliolum, A. variabilis, Anacystis nidulans, Spirulina maxima, Nostoc calcicola, N. muscorum, and Brevibacterium ammoniagenes), and Actinomycetes (Streptomyces aureofaciens) (Hasan, 2000). The microbial urease activity is greatly influenced by temperature, $\mathrm{pH}$ (with an optimal of 7-8.7 except for acid-urease activity), concentration of urea and the end product ammonia, carbon source, and incubation period (Hasan, 2000).

The genus Bacillus is the most common ureolytic bacteria used for biotechnology. They typically are Gram-positive, aerobic, and rod-shaped prokaryotic cells with a size of 1-10 $\mu \mathrm{m}$ (Martin et al., 2012; Wong, 2015). They are particularly interesting for MCP technology due to their capability of producing $\mathrm{CO}_{2}$ paralleled by increasing $\mathrm{pH}$ in the surrounding environment (Sel et al., 2015; Wei et al., 2015). Both respirations by cells and the decomposition of urea provide a source of $\mathrm{CO}_{2}$. For example, Bacillus diminuta, one of the most effective carbonatogenic bacterium, was isolated from decayed building stones (Jroundi et al., 2010). Other Bacillus species, such as B. lentus, habitat in soil, marine, and sediments (Proom and Knight, 1955; Belliveau et al., 1991; Siefert et al., 2000), are widely used in industry to produce alkaline protease (Jørgensen et al., 2000).

\section{Denitrification}

Under anaerobic conditions, nitrate is used by microorganisms to oxidize organic compounds for energy and cell growth (Martin et al., 2013). A number of bacteria capable of reducing nitrate, the so-called denitrifies, includes Alcaligenes, Bacillus, Denitro bacillus, Thiobacillus, Pseudomonas, Spirillum, Micrococcus, and Achromobacter (Karatas, 2008). Denitrifiers are typically facultative anaerobes, providing them flexibility in their growth strategy (Karatas, 2008). Due to its highly negative standard Gibbs free energy $\left(\Delta \mathrm{G}^{\circ}\right)$, denitrification can be expected to dominate where nitrate and organic carbon is present and $\mathrm{O}_{2}$ is limited (Dejong et al., 2010). 

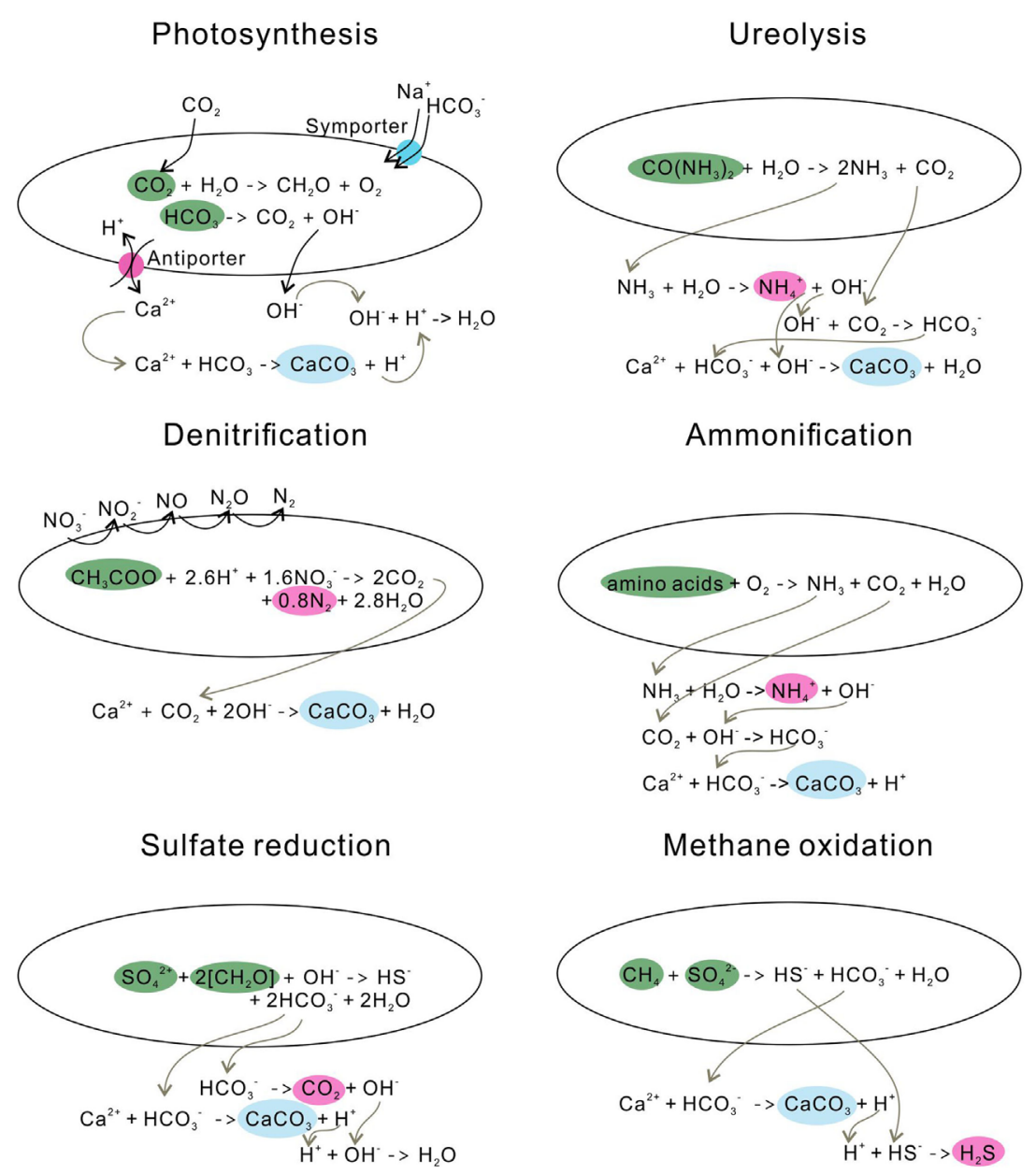

FIGURE 3 | Microbial carbonate precipitation induced by different metabolisms.

The denitrification process increases the $\mathrm{pH}$ in the surrounding medium by consuming $\mathrm{H}^{+}$, and produces $\mathrm{CO}_{2}$, which favors carbonate precipitation (Table 1; Figure 3). Till now, only a few studies have investigated the direct link between denitrification and calcium carbonate formation, and observed calcium carbonate crystals precipitate around the cells during denitrification (Erşan et al., 2015b).

The by-product generated during this process is $\mathrm{N}_{2}$, which is harmless (Van Paassen et al., 2010). However, toxic nitrite and nitrous oxide might accumulate if any of four different enzymes involving in the denitrification process are inhibited (Van Paassen et al., 2010).

\section{Ammonification of Amino Acids}

The ammonification of amino acids through microbial metabolisms produces $\mathrm{CO}_{3}^{2-}$ and $\mathrm{NH}_{3}$ (González-Muñoz et al., 2010) (Figure 3). The subsequent hydrolysis of $\mathrm{NH}_{3}$ generates $\mathrm{OH}^{-}$ around cells and leads to a high local supersaturation with respect to calcium carbonate, and, consequently, precipitates calcite or vaterite (González-Muñoz et al., 2010).

Some species, which are representers of myxobacteria, e.g., Myxococcus xanthus serve as a nucleation template for carbonate precipitation (Chekroun et al., 2004). Their main characteristics, aside from being Gram-negative, aerobic, non-pathogenic, heterotrophic, and rod-shaped, are that they can use amino acids as their sole energy source (Dworkin, 1993; Gerth et al., 2003). These soil bacteria are abundant in almost all environments and play an essential role in the degradation of organic material (Omar et al., 1995).

\section{Sulfate Reduction}

Sulfate-reducing bacteria (SRB) reduce sulfate to sulfide while oxidizing organic carbon to bicarbonate (Table 1), during which $\mathrm{pH}$ and saturation state are increased (Baumgartner et al., 2006) (Figure 3). On the other hand, SRB can increase the local $\mathrm{Ca}^{2+}$ concentration by degrading EPS of cyanobacterial mats or excreting $\mathrm{Ca}^{2+}$ from cells (Visscher et al., 2000; Plée et al., 2010). With the increase of $\mathrm{HCO}_{3}^{-}$concentration and the release of $\mathrm{Ca}^{2+}$, it favors $\mathrm{CaCO}_{3}$ precipitation.

In addition, even the metabolically inactive SRB cells, e.g., D. desulfuricans strain G20, may lead to calcium carbonate precipitation by providing heterogeneous nucleation sites (Bosak and Newman, 2003). Both their cell surface and EPS impact the 
calcium carbonate precipitation (Braissant et al., 2007). In many field studies, carbonate precipitation by SRB was observed in microbial mats underneath the surface layers where cyanobacteria are active (Baumgartner et al., 2006).

\section{Methane Oxidation}

Anaerobic oxidation of methane favors the precipitation of calcium carbonate, whereas aerobic oxidation of methane leads to the dissolution of carbonates by increasing acidity (Reeburgh, 2007) (Table 1). In the anaerobic oxidation, methane is oxidized to bicarbonate, and sulfate is reduced to $\mathrm{HS}^{-}$. In the presence of $\mathrm{Ca}^{2+}$, calcium carbonate is precipitated, and hydrogen sulfide is generated (Figure 3).

Indicated by methane profiles, radiotracers, and a stable carbon isotope, a large portion of the methane is converted to $\mathrm{CO}_{2}$ through anaerobic oxidation in marine sediments (Boetius et al., 2000). In present-day environments, while aerobic methanotrophs have been identified, no organisms consuming methane anaerobically have ever been isolated (Hinrichs et al., 1999).

\section{Microbial Carbonate Precipitation in Natural Environments}

Environmental conditions influence the native bacterial community, which in turn alters the environment through its metabolic activities (Dupraz et al., 2004). In a wide range of modern and ancient geological environments, such as caves, soils, fresh and marine water, and hot springs, the precipitation of carbonate minerals is impacted and governed by microbes (Krumbein et al., 2003). The carbonate products include marine reefs, tidal flats, lacustrine whitings, fluviatile tufas, hot-spring travertines, and cave crusts, as well as subaerial calcretes and other coatings, grains, and matrices within sediment (Riding, 2000).

Aquatic environments, both marine and freshwaters, have been extensively studied in regards to MCP. This is reflected in the amount of publications on the topic: by searching the common keywords of ("carbonate precipitation" OR "calcite precipitation" OR calcification) AND (microb* OR microorganism), and the additional keyword of soil, cave, freshwater, hypersaline, marine, and "hot spring," it results in 468, 57, 188, 61, 928, and 18 articles, respectively.

In terrestrial systems, the main attention among the metabolic processes has been paid to ureolysis, accounting for $43 \%$ among all the metabolisms (Figure 4). "Ureolysis" is followed by "cyanobacteria AND photosynth*", which accounts for $38 \%$. In the cave and hypersaline environments, both ureolysis and photosynthesis consist of half of the studies on MCP. In freshwater and marine environments, the photosynthesis by cyanobacteria is the most common metabolic process for carbonate precipitation, followed by "sulfate reduction." In hot-spring environments, only photosynthesis by cyanobacteria is reported.

\section{Caves}

Caves are characterized by high humidity and relatively low and stable temperature. In many cases, they are oligotrophic environments due to the spatial isolation and low energy supply for any kind of metabolic activities (Gherman et al., 2014).

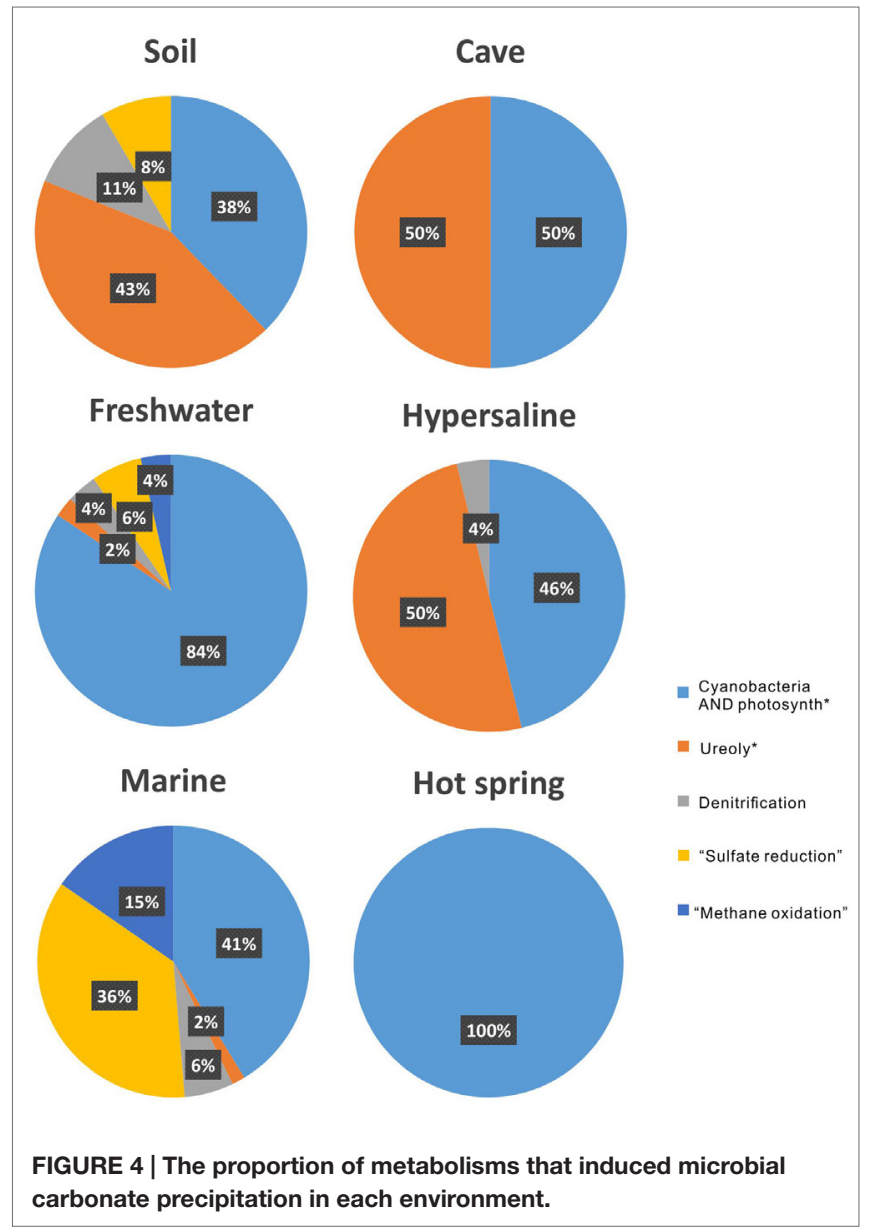

Although calcite formations in caves were believed to be an abiotic process, recent studies suggest that microorganisms may actively participate in the formation of stalactites and stalagmites in caves (Banks et al., 2010). The presence of $\mathrm{CO}_{2}$, high calcium concentration, and urea might have contributed to the biomineralization in such habitat (Liu et al., 2010). Notably, in calcium-rich environments, cells have to deal with toxic $\mathrm{Ca}^{2+}$ ions as well (Anderson et al., 1992). Indeed, by examining the calcification phenotype of numerous bacterial species and by using a knock-out in the chaA calcium antiporter protein, it is suggested that calcification is the $\mathrm{Ca}^{2+}$ ions detoxifying strategy taken by cells (Banks et al., 2010).

Photosynthetic microorganisms, such as cyanobacteria, have been implicated in forming stromatolitic carbonate speleothems in the photic zone of carbonate caves (Cañveras et al., 2001; Léveillé et al., 2007). An elevated ${ }^{13} \mathrm{C}$ value of calcium carbonate indicates the preferential uptake of ${ }^{12} \mathrm{C}$ by photosynthetic microorganisms within the mats (Léveillé et al., 2007).

By introducing urea to caves through the urine of mammals (Johnston et al., 2012), and from infiltration from the surface (Ortiz et al., 2013), it is possible for ureolytic bacteria to grow, sequestrate $\mathrm{CO}_{2}$, and precipitate carbonates as well (Okyay and Rodrigues, 2015). 


\section{Soil}

Bacteria are omnipresent in soils at surprisingly high concentrations, almost regardless of saturation, mineralogy, $\mathrm{pH}$, and other environmental factors (De Jong et al., 2013; Sel et al., 2015). Microbial activities can alter the texture of soil and improve its strength by precipitating carbonates and binding soil particles (Sari, 2015). Microbialites have been found in desert soils and tropical forest soils as well (Garcia-Pichel et al., 2003; Cailleau et al., 2004).

Ureolytic bacteria, such as S. pasteurii, Pseudomonas calcis, Bacillus sp., and Pseudomonas denitrificans, are widespread in the soil environment, and perform carbonate precipitation (Boquet et al., 1973; Hamdan et al., 2011; Meyer et al., 2011; Chu et al., 2012). Among them, $S$. pasteurii is widely studied due to its highly active urease enzyme, which catalyzes the reaction network toward the precipitation of calcite (Fujita et al., 2000; Hammes et al., 2003).

Myxococcus, usually found in soil that is rich in organic matter and decaying material, can precipitate calcium carbonate independently of being metabolically active or killed, though different polymorphs of calcite can be formed (Rodriguez-Navarro et al., 2003; Chekroun et al., 2004).

\section{Freshwater Bodies}

Depending on the primary production, freshwater bodies can be categorized into oligotrophic, mesotrophic, eutrophic, and hypereutrophic ones. The phenomenon of carbonate precipitation, commonly referred to as whiting, is well known in many eutrophic and mesotrophic lakes, such as Lake Erie and Lake Ontario (Hodell et al., 1998). Moreover, carbonate precipitation can take place even in oligotrophic lakes (Dittrich et al., 2004).

It is suggested that picocyanobacteria are responsible for the carbonate precipitation in these lakes (Dittrich and Obst, 2004). With the impact of the cell surface and photosynthesis, a microenvironment supersaturated with respect to calcite is created (Andrews et al., 1997). In freshwater, the carbonate is usually precipitated on or impregnate with cyanobacterial sheaths or cells (Freytet and Plet, 1996; Freytet and Verrecchia, 1998; Dupraz et al., 2009a).

Calcification of cyanobacterially dominated mats and biofilm can create thick lithified crusts on stream beds and around pebblesized oncoid nodules (Pedley, 1990; Merz-Preiß and Riding, 1999). In all, calcified cyanobacteria are locally abundant in freshwater streams and lakes (Golubic, 1973). Microbialites, such as travertine, can be found in freshwater lakes (Dupraz et al., 2009a).

\section{Hypersaline Lakes}

A hypersaline lake contains a significant concentration of sodium chloride or other salts, with saline levels surpassing that of ocean water. Extensive carbonate precipitates associated with microbial mats are quite common in hypersaline lakes (Glunk et al., 2011). For example, carbonate hardgrounds, crusts, and microbialites are abundant in hypersaline lakes, and they can extend from $500 \mathrm{~m}$ inland to several tens of meters offshore and into water depths of up to $2 \mathrm{~m}$ (Last et al., 2010). Microbialites, from leiolite to thrombolite, have been discovered in hypersaline lakes as well (Dupraz et al., 2004, 2009a).
The mechanism of the MCP in hypersaline lakes is still controversial. Whether it is phototrophs or heterotrophs that play a key role in the calcification is disputable. It is reported that the metabolic reactions of cyanobacteria and SRB promote calcium carbonate precipitation, and those of aerobic heterotrophic bacteria and many sulfide-oxidizing bacteria favor dissolution (Freytet and Verrecchia, 1998; Baumgartner et al., 2009). Both phototrophs and heterotrophs can increase $\mathrm{pH}$ through their metabolic activity, and the alteration of the saturation index in mats can represent a combined community effort (Dupraz and Visscher, 2005; Vasconcelos et al., 2014).

According to Ludwig et al. (2005), the increase of $\mathrm{Ca}^{2+}$ concentration is mainly due to the EPS degradation by SRB, and the driving factor of carbonate precipitation lies in the increased concentration of $\mathrm{CO}_{3}^{2}$ by photosynthetic bacteria. However, other studies suggest that heterotrophic bacteria, including alkaliphilic and halophilic species, SRB, and ureolytic bacilli, may play a crucial and direct role in carbonate precipitation (López-García et al., 2005).

In addition to influencing the calcium carbonate equilibrium through their metabolism, the microbial community also controls the formation, characteristics, and degradation of EPS, which play an intricate role in the production of calcium carbonate by serving as a template for a crystal growth (Dupraz and Visscher, 2005).

\section{Marine Environments}

Over geological timescales, the process of $\mathrm{CaCO}_{3}$ biomineralization has had a great significance for the fossil record in marine environments (Arp et al., 2001; Riding and Liang, 2005). The forms of carbonate deposits include stromatolites, thrombolites, and carbonated sediment (Riding and Liang, 2005). These formations are a result of calcification by microbial mats and biofilms, commonly dominated by cyanobacteria and/or non-phototrophic bacteria (Arp et al., 2001). The stromatolites in open marine environments are usually laminated and coarse grained (Dupraz et al., 2009a). Both the saturation state of seawater with respect to calcium carbonate (Webb, 2001) and the biomineralization processes (Bosscher and Schlager, 1993) control the marine carbonate precipitation. Microorganisms facilitate $\mathrm{CaCO}_{3}$ precipitation by creating a favorable chemical microenvironment for carbonate precipitation by active excretion of $\mathrm{Ca}^{2+}$, which can be toxic for cells at seawater concentrations (Banks et al., 2010).

Cyanobacteria (Schoon et al., 2010) and SRB (Visscher et al., 2000) are proposed to promote the calcium carbonate precipitation. The increased alkalinity resulting from the sulfate reduction and $\mathrm{Ca}^{2+}$ released from cyanobacterial EPS lead to the $\mathrm{CaCO}_{3}$ precipitation (Dupraz et al., 2009a). However, other studies suggested that photosynthetically induced $\mathrm{pH}$ and $\mathrm{CO}_{3}^{2-}$ increases control calcification, rather than sulfate reduction (Ludwig et al., 2005; Planavsky et al., 2009; Vasconcelos et al., 2014).

\section{Hot Springs}

Travertine is a common form of limestone deposited in hot springs. Whether it is an abiotic or biotic process that contributes to the formation of travertine is still controversial (Fouke, 2011). Photoautotrophs and heterotrophs are active in hot springs 
where the temperature is higher than $36.5^{\circ} \mathrm{C}$, and in some cases exceed $60^{\circ} \mathrm{C}$ (Martín and Goldenfeld, 2006; Pedley, 2009), and cyanobacteria have been identified as the main oxygenic photosynthetic microbes (Pentecost, 2003). It is reported that at least three-quarters of carbonate precipitation at $51^{\circ} \mathrm{C}$ in the Le Zitelle site in Central Italy was microbial mediated (Folk, 1994). With the trace of carbon isotope, it is demonstrated that many dendritic pool precipitates are microbially influenced (Guo et al., 1996). Cyanobacteria, such as Thermosynechococcus elongatus, were found to be closely associated with aragonite in the biofilm and microbial mat (Okumura et al., 2013). However, other studies suggest that travertine deposits are produced by a combination of SRB and cyanobacteria metabolic activity (Tekin et al., 2000).

\section{POTENTIAL BIOTECHNOLOGICAL APPLICATIONS OF MCP}

Calcium carbonate is used commercially for a variety of applications, and yet a wide range of potential uses are under development. For example, the low-cost of calcium carbonate makes it an ideal filler for plastic, rubber, and paper (Sarayu et al., 2014). Recently, microbial precipitated calcium carbonate has shown an advantage by altering the fluorescent property. The calcite crystals formed by thermophilic Geobacillus thermoglucosidasius have wide emission wavelengths of 350-600 nm (Yoshida et al., 2010), making them a perfect material as fluorescent particles in stationary ink. Compared with conventional metal-oxide-type phosphors, calcite nucleated by G. thermoglucosidasius is more stable and does not require precious rare earth. Instead, they incorporate magnesium, sodium, sulfur, and phosphorus atoms in the carbonate host lattice. It has been suggested that the fluorescence is caused by organic substances, especially humic compounds that is dispersed in the calcite (Lauritzen et al., 1986). The coprecipitation of divalent metals with calcium carbonate can be applied to remove heavy metals and radionuclide (Reeder et al., 1999). The cementitious property makes calcite suitable for $\mathrm{CO}_{2}$ sequestration, MEOR, and the restoration of construction materials (Figure 5). Photosynthesis, ureolysis, ammonification, and denitrification induced carbonate precipitation has been applied in these biotechnology (RodriguezNavarro et al., 2003; Dick et al., 2006; Ramanan et al., 2010; Erşan et al., 2015b).

\section{Metal and Radionuclide Remediation}

The discharge of heavy metals (e.g., copper, arsenic, and chromium) from mining and metal-processing industries has led to serious contamination in soil and groundwater. Remediation of contaminated sites with a cost-effective and eco-friendly technique is of urgent need. Conventional methods, such as chemical reactions, ion exchange, electrochemical treatment, and membrane technologies are either ineffective or extremely expensive (Ahluwalia and Goyal, 2007). Redox interactions leading to decreased solubility of heavy metals has a risk of remobilization if, in the future, the changes in oxidation-reduction potential occur.

In comparison, $\mathrm{CaCO}_{3}$-based coprecipitation offers a stable, redox-insensitive solution (Phillips et al., 2013). Heavy metal ions

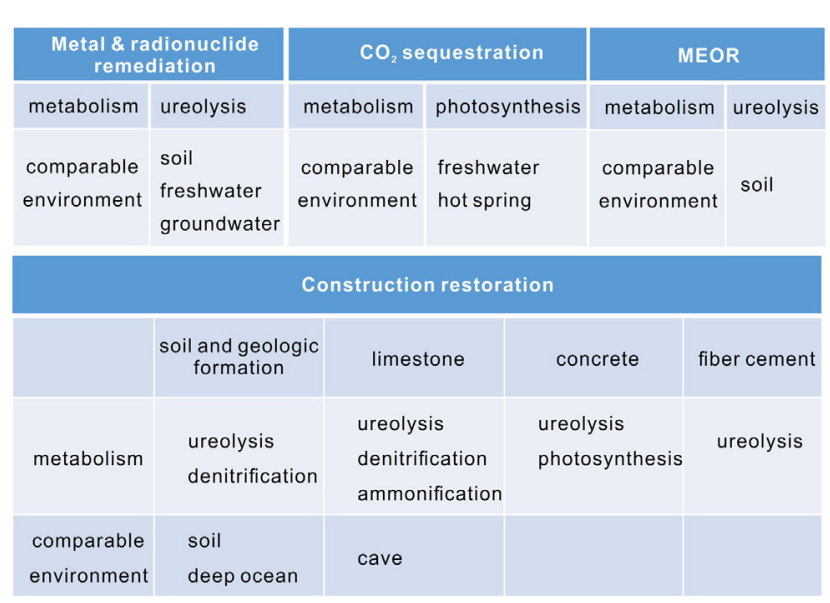

FIGURE 5 | The application areas of microbial carbonate precipitation, their main metabolisms and comparable environments.

with an ion radius close to $\mathrm{Ca}^{2+}$, such as $\mathrm{Sr}^{2+}, \mathrm{Pb}^{2+}, \mathrm{Co}^{2+}$, and $\mathrm{Zn}^{2+}$, can be incorporated into the calcite crystal by substituting the $\mathrm{Ca}^{2+}$ in the lattice, or by entering the interstice or defect of crystal (Reeder et al., 1999; Finch and Allison, 2007).

Ureolysis-involved MCP is a novel remediation approach to capture divalent heavy metals and radionuclides. Although in elevated concentrations, heavy metals may inhibit the growth of ureolytic bacteria (Kurmaç, 2009), the MCP has shown positive results in a highly concentrated heavy metal solution. For example, carbonates induced by Kocuria flava removed 97\% of copper with an initial Cu concentration of $1000 \mathrm{mg} / \mathrm{L}$ (Achal et al., 2011b). MCP induced by Bacillus cereus in remediated soil has remarkably decreased the amount of Cr (Kumari et al., 2014), while MCP by Lysinibacillus sphaericus removed $99.95 \%$ of Cd after incubation of $48 \mathrm{~h}$ (Kang et al., 2014). Sporosarcina ginsengisoli-induced MCP significantly removed from the aqueous solution (Achal et al., 2012). Furthermore, the efficiency of ureolytic bacteria to bind various types of heavy metal ions is due to their large surface area and availability of anions on the cell surface (Wong, 2015).

Soils and groundwater contaminated with radionuclides, particularly ${ }^{137} \mathrm{Cs}$ and ${ }^{90} \mathrm{Sr}$, pose a long-term radiation hazard to human health. Remediation of radionuclide-contaminated land by carbonates has attracted increasing attention. The high stability of carbonates and the potential for coprecipitation of radionuclides is an appealing engineer application (Lauchnor et al., 2013). ${ }^{90} \mathrm{Sr}$, a uranium fission by-product, is readily coprecipitated with $\mathrm{CaCO}_{3}$ (Curti, 1999). It is possible for ${ }^{90} \mathrm{Sr}$ to decay in sequestrated carbonates due to the short half-life of ${ }^{90} \mathrm{Sr}$ (29 years) and the stability of calcite (Lauchnor et al., 2013). MCP induced by ureolytic activity has been examined in detail and has been shown to increase the rate of calcite precipitation and lead to Sr coprecipitation (Fujita et al., 2004; Brookshaw et al., 2012). MCP by B. pasteurii captured $95 \%$ of total strontium at an initial concentration of $1 \mathrm{mM}$ within $24 \mathrm{~h}$, and the efficiency is much higher than that of $\mathrm{UO}_{2}$ and $\mathrm{Cu}$ (Warren et al., 2001). By controlling the concentration of carbon source and modifying the 
injection strategy, even higher Sr coprecipitation efficiency can be achieved (Fujita et al., 2008; Lauchnor et al., 2013).

\section{$\mathrm{CO}_{2}$ Sequestration}

The Intergovernmental Panel on Climate Change assessment (Field and Van Aalst, 2014) reported a warming of $0.85^{\circ} \mathrm{C}$ over the period from 1880 to 2012 . Three strategies are proposed to mitigate the climate change (Schrag, 2007): (1) reducing the global energy use, (2) depending on zero-carbon-print energy, and (3) sequestrating $\mathrm{CO}_{2}$.

Geological sequestration has a potential risk of upward leakage of $\mathrm{CO}_{2}$ through fractures, disturbed rock, or cement lining near injection wells (Cunningham et al., 2009). By contrast, mineral sequestration offers an inexpensive, low-risk, and long-term storage strategy (McCutcheon et al., 2014). Microbial $\mathrm{CO}_{2}$ fixation is an emerging and promising technology, and it is considered to be reliable and economically sustainable to mitigate greenhouse gas (GHG) emissions (Rossi et al., 2015). Photosynthetic microbes, such as cyanobacteria and microalgae, play a notable role in carbon sequestration by simultaneously capturing $\mathrm{CO}_{2}$, generating power, and producing biodiesel (Wang et al., 2010; Kumar et al., 2011).

Microalgae and cyanobacteria can survive in a wide range of $\mathrm{CO}_{2}$ concentrations using $\mathrm{CO}_{2}$ concentrating mechanism (CCM) (Badger and Price, 1992). By using Chlorella sp. and Spirulina platensis, the $\mathrm{CO}_{2}$ sequestration efficiency was improved to 46 and $39 \%$, respectively (Ramanan et al., 2010). It is possible to fix $\mathrm{CO}_{2}$ at a rate of 33 ton of/C/ha/year in combined mineral and biological storage (McCutcheon et al., 2014). The extensive production of EPS has been demonstrated to be the main factor to accelerate carbonate mineralization (Obst et al., 2009). The biological fixation of $\mathrm{CO}_{2}$ can be affected by $\mathrm{pH}, \mathrm{O}_{2}$ removal, the proper agitation of the reactor, the availability of light, and the appropriate design of bioreactors (Kumar et al., 2011). Compared to vertical tubular and bubble column photobioreactors, airlift-type photobioreactors were found to be the most suitable technique.

No net sequestration of $\mathrm{CO}_{2}(\mathrm{~g})$ was observed through the ureolysis by $S$. pasteurii, indicated by the mole of calcite precipitated being equal to or less than the moles of urea-derived carbonate ions (Mitchell et al., 2010). This is due to the generation of $\mathrm{CO}_{2}$ in the process of urea hydrolysis (Figure 3). Nevertheless, MCP through ureolysis provides several engineering advantages, including bioaugmentation of native organisms, utilizing wastewater urea sources, and decreasing the formation porosity.

\section{Microbial Enhanced Oil Recovery}

As an important energy source, crude oil plays a crucial role in economy, politics, and technology. Oil recovery from oil wells is conducted in two phases: (1) about $10-15 \%$ of the original oil in place (OOIP) is recovered in the primary phase and (2) about $15 \%$ of OOIP is recovered in the secondary phase by water flooding (Suthar et al., 2009). By the end of the conventional oilrecovery methods, almost $65 \%$ of oil is left behind in the reservoir. EOR is necessary to improve the overall extraction percentage. However, EOR, which involves thermal or chemical flooding processes, is environmentally hazardous, costly, and leaves undesirable residues that are difficult to dispose (Suthar et al., 2009).
In comparison, MEOR offers a cost-effective and eco-friendly strategy. Most commonly, MEOR utilizes microbes to produce biosurfactants, biopolymers, acids, gases, and solvents to reduce interfacial tension between oil-and-water and oil-and-rock interfaces (Sen, 2008). To a lesser extent, MEOR uses bacteria to plug high-permeability zones and lead to a redirection of waterflood, therefore improving the yield of reservoir oil (Dejong et al., 2006).

Inspired by a natural process of microbial carbonate cementing of marine sediments in lagoons and reefs, bacteriogenic mineral plugging to enhance the oil recovery is patented (Ferris and Stehmeier, 1992). The bacterial slurry can be injected into the subsurface environment, predominantly entering highly permeable zones, adhering to the rock/sand surfaces, and precipitating minerals in situ to plug porous media (Sen, 2008). EPS producing bacteria selectively block the high-permeability zones, therefore redirect water to flow through the low permeability zones and lead to an increase in oil recovery (Suthar et al., 2009). A variety of Bacillus strains are suitable to plug pores by producing EPS and minerals (Sen, 2008). S. pasteurii can be used for MEOR, since they naturally occur in the subsurface and do not aggregate, which ensures a high cell surface-to-volume ratio (Dejong et al., 2006). Under subsurface conditions, factors, such as $\mathrm{pH}$, oxygen supply, metabolic status, nutrients, fluid flow, and concentration of microbes and ionic calcium, are critical for the success of the microbial treatment (Fratesi, 2002; Dejong et al., 2006).

\section{Restoration of Construction Materials}

The MCP has shown its merits in improving the mechanical properties of porous materials (Le Metayer-Levrel et al., 1999; Montoya et al., 2013). It not only strengthens underground conditions for constructions, such as soil or geological formation (Whiffin et al., 2007; Harkes et al., 2010; Mahanty et al., 2013), but also restores aboveground structures, such as limestone-based monuments and concrete structures (Tiano et al., 1999; Castanier et al., 2000; Jimenez-Lopez et al., 2007; De Belie and De Muynck, 2009).

\section{Soil and Geological Formation Reinforcement}

The mechanical properties (cohesion, friction, stiffness, and permeability) are important for soil, which serves as a basis for roads, railways, dikes, dunes, and slopes (Harkes et al., 2010). Stabilization of soil for desired land uses is required, since the mechanical properties of those engineering constructions are typically insufficient. Chemical grouting, one of the soil-strengthening techniques, is costly and requires many injection wells for treating large volumes (Van Paassen et al., 2010). Biogrout, involving MCP in situ, provides a sustainable solution.

To cement the porous soil or geological formation by MCP, a large amount of calcium carbonate is needed. However, highly concentrated calcium and inorganic carbon solution in the subsurface would lead to immediate uncontrolled precipitation and would limit injection distance. Furthermore, the simultaneous injection of slightly oversaturated solution of calcium and inorganic carbon would require enormous amounts of liquid volume to induce sufficient precipitation. Therefore, with the injection of a high concentration of dissolved calcium, both inorganic 
carbon and alkalinity have to be sufficiently produced in situ (Van Paassen et al., 2010).

Most of the biogrout studies were based on calcium carbonate precipitation induced by hydrolysis of urea (Harkes et al., 2010). The biomineralization of ureolytic bacteria S. pasteurii has significantly increased the soil strength (Dejong et al., 2006). The investigation of biofilm and mineral deposits by $S$. pasteurii in flowing and non-flowing columns shows a potential mitigation of controlling $\mathrm{CO}_{2}$ leakage during geological sequestration (Cunningham et al., 2009).

Additionally, other metabolic pathways, such as aerobic oxidation, nitrate reduction, and sulfate reduction, have been investigated for MCP (Van Paassen et al., 2010). Unlike urea hydrolysis generating ammonium chloride as an unfavorable side product, nitrogen gas and $\mathrm{CO}_{2}$ produced by the denitrification process are harmless (Van Paassen et al., 2010). With insufficient reaction, however, intermediate compounds, such as nitrite and nitrous oxide, may accumulate (see Denitrification).

Microbial carbonate precipitation was applied in a large-scale soil-improvement project (Whiffin et al., 2007). Techniques, such as the fixation and distribution of bacteria, the balancing of the flow and reaction rate, and the controlling of the injection rate, have been developed to improve cementation uniformity (Whiffin et al., 2007; Harkes et al., 2010; Martinez et al., 2013). The engineering properties of soils, such as permeability, stiffness, shear strength, and volumetric response, have been greatly improved (Dejong et al., 2010; Martinez et al., 2013). Meanwhile, MCP for soil reinforcement reduces cost and the impact on the environment (Dejong et al., 2010).

\section{Limestone Restoration}

Limestone monuments and buildings are subject to deterioration due to weathering. In order to protect historical objects, many conservation treatments have been introduced to consolidate limestone before irreversible damage occurs. Organic and inorganic materials, such as epoxy resins and $\mathrm{Ba}(\mathrm{OH})_{2}$ solutions, treated on deteriorated stones are either adverse to the environment or provide insufficient consolidation (Rodriguez-Navarro et al., 2003). Recently, MCP has been proposed to treat decayed monuments, statues, and buildings.

Ureolytic-driven calcium carbonate precipitation has been applied in limestone restoration. B. subtillis was discovered to produce rhomboedral calcite crystals and decrease the stone porosity (Tiano et al., 1999). A comparison of B. sphaericus and $B$. lentus demonstrated that B. sphaericus strains with a very negative $\xi$-potential and a high initial urea degradation are most suitable for coherent calcite production on deteriorated limestone (Dick et al., 2006). In 1993, the first application on the tower of the Saint Médard Church exhibited a substantial reduction of water absorption (Le Metayer-Levrel et al., 1999). Another application on the church of Santa Maria in Italy stated that the MCP treatment did not influence the esthetic appearance (Tiano and Cantisani, 2005).

Microbial carbonate precipitation induced by ammonification of amino acids has been applied on decayed limestone as well. B. cereus, isolated from soil, was one of the pioneers to be used in preserving a historic property (Castanier et al., 2000).
M. xanthus is capable of producing a coherent carbonate cement strongly attached to limestone (Rodriguez-Navarro et al., 2003). The organic-inorganic composites make new crystals more stress resistant than the calcite grains of the original stone. Furthermore, the mineralogy and morphology of the precipitates can be manipulated by changing the composition of culture medium.

\section{Concrete Restoration}

Concrete is the most widely used construction material in the world (Ai"Tcin, 2000), and its global production is expected to increase until 2050 (Müller and Harnisch, 2008). Even though the durability, cost-effectiveness, high compressive strength, design flexibility, and fire resistance make concrete extraordinarily popular, cracks in concrete are quite common due to freeze-thaw conditions and de-icing chemicals. There are a large number of products available commercially for repairing cracks in concrete, varying from water repellent and stone consolidation to organic treatments and inorganic consolidation. However, these conventional treatments have a number of disadvantages, such as (1) different thermal expansion coefficient of the treated layers, (2) degradation over time, (3) the need for constant maintenance, and (4) the contribution to environmental pollution (De Muynck et al., 2008a).

Recently, researchers proposed the use of MCP in concrete constructions although it is challenging due to the extremely high pH of concrete fluid (Bang et al., 2001). Positive results, such as the improvement of compressive strength, the enhancement of durability, and a decrease of water absorption and permeability, were observed in laboratory studies (Ramakrishnan et al., 1998; De Muynck et al., 2008b; De Belie and De Muynck, 2009). A freeze-thaw cycle experiment demonstrates that the MCP treatment greatly enhances the durability of concrete beams (Bang et al., 2010). A decrease of water absorption rate was observed with the MCP treatment, which improves the resistance of cementations materials toward degradation processes (De Muynck et al., 2008b; Achal et al., 2011a). Compressive strength, one of the most important parameters evaluating the quality of concrete, was significantly increased by the MCP process (Ramachandran et al., 2001; Ramakrishnan, 2007; Bang et al., 2010; Wang et al., 2012). An autonomous repair concrete was developed by casting concrete slabs with Bacillus spores and calcium lactate nutrients that are embedded into clay pellets separately (Jonkers and Schlangen, 2009). When cracks form in the concrete, water will enter and open up the pellets, causing the bacteria to germinate and produce calcite (Jonkers and Schlangen, 2009). Since it is a relatively new technology and the concrete life span is around 30 years, the effectiveness of the real application is still under evaluation.

A life cycle-assessment shows that the overall environmental impact of bioconcrete is half that of concrete (Gonsalves, 2011). Bioconcrete excels concrete by having a lower contribution of carcinogens (one-thirtieth), ecotoxicity (one-tenth), climate change (half), and fossil fuels (six-sevenths). The main deficiencies of the ureolytic bioconcrete are the generation of ammonia and the pathogens that are associated with the activity of ureolytic bacteria (Mobley and Hausinger, 1989; Benini et al., 1999). To lower the environmental impact, autophototrophic cyanobacteria were 
proposed and investigated. They showed a potential to serve as a green technology in concrete restoration (Zhu et al., 2015). It is the first study that shows a thick calcite/cell-aggregate layer precipitated by cyanobacteria on the concrete surface, and decreased water absorption.

\section{Fiber Cement}

Fiber cement tiles are a fire-resistant and low-cost material usually used for roofing. However, the colonization of biofilm on its surface would reduce its reflectivity (Shirakawa et al., 2014). Recently, carbonate precipitation by ureolytic bacteria has been tested on fiber cement to improve its reflectivity (Shirakawa et al., 2015). After exposure to the environment for 22 months, fiber cement treated with $B$. sphaericus was not degraded by fungi or phototrophs. Therefore, it is a potential treatment to avoid the fouling-associated darkening of fiber cement tiles.

\section{CHALLENGES IN MCP BIOTECHNOLOGY}

Even though MCP has been successfully demonstrated in the laboratory for many cases, its real application in the field is facing numerous challenges (Figure 6). Since the conditions in the field cannot be controlled as in the laboratory, microorganisms are likely to suffer from harsh and changing environments. In addition, the generation of undesired by-products and uncontrolled growth has to be avoided. The upscaling of the MCP from the laboratory condition to the field environment might confront technical difficulties in injecting nutrients, chemicals, and cultures; obtaining homogeneous treatment; and monitoring the remediation process.

\section{Limitations of Microorganisms Extreme Conditions}

In the practical application, microorganisms are often exposed to harsh conditions, such as desiccation, oxygen and nutrient deficiency, high $\mathrm{pH}$, pressure, temperature, and salt concentration.

Desiccation occurs in the MCP application of concrete restoration. When concrete is exposed to ambient air, the moisture content of the concrete structure decreases due to the moisture diffusion (Kim and Lee, 1998). An additional decrease of the moisture content can be caused by the hydration of cement at early ages (Persson, 1997). Besides this restriction for microbial life, the harsh environment of concrete with extremely high $\mathrm{pH}$ can be handled by only a few bacteria. These factors lead to the limitation of bacterial strains for concrete restoration. The most widely used bacteria, $S$. pasteurii, is a moderate alkaliphile with a pH optimum for growth of 9.2 (Mobley et al., 1995).

Aerobic microorganisms, such as ureolytic bacteria and myxobacteria, are used in numerous laboratory studies (Rodriguez-Navarro et al., 2003; De Muynck et al., 2010). While

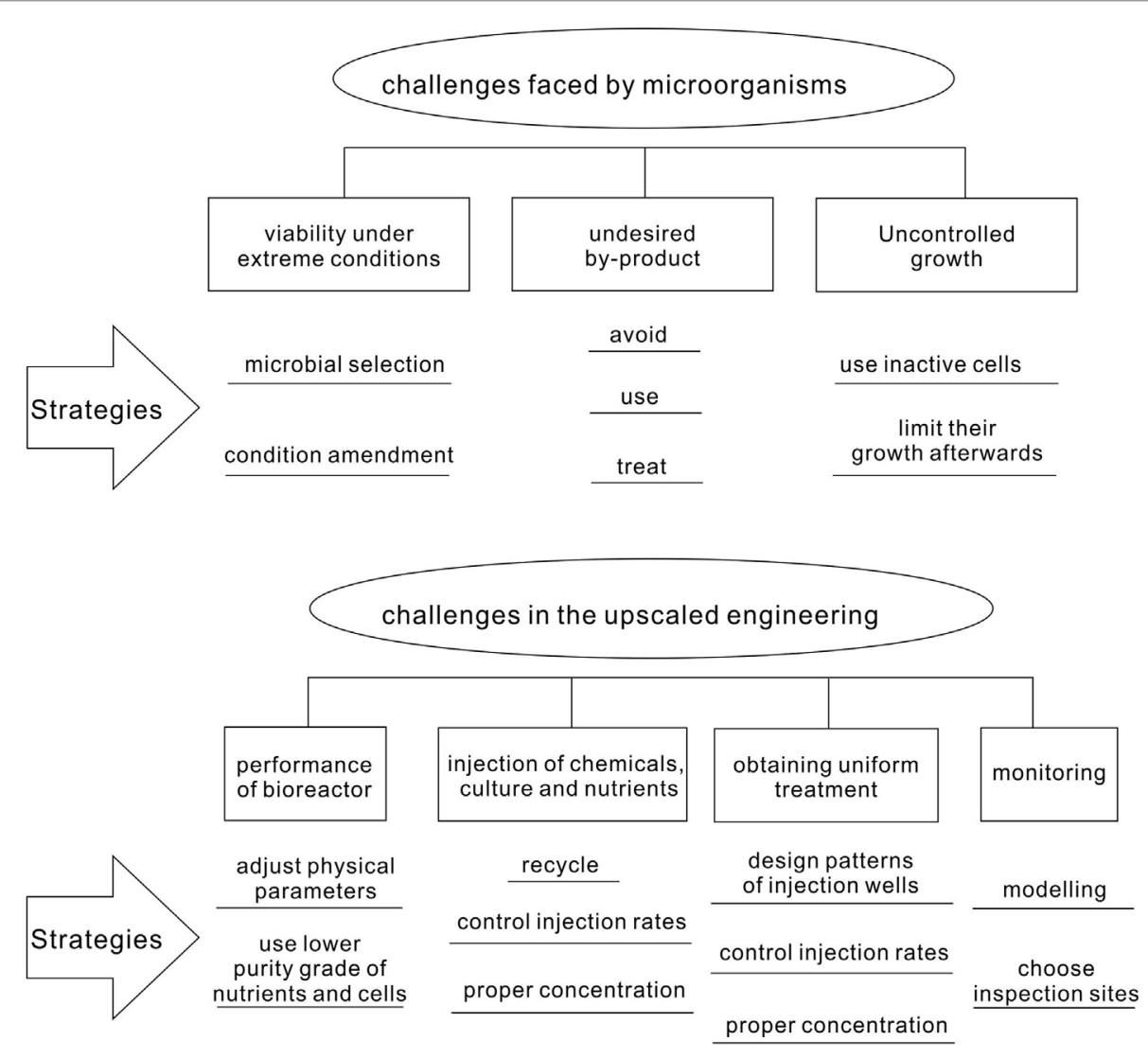

FIGURE 6 | Challenges faced in the real application of microbial carbonate precipitation. 
their application in limestone and concrete restoration, metal remediation, and soil reinforcement in shallow subsurface are promising, their long-term use under anaerobic conditions, such as deeper parts of geological formation, groundwater, and oil reservoir, are questionable (De Jong et al., 2013). There are still many open questions, e.g., Can they survive until the objective is reached? Even if their growth is not inhibited under this unfavorable condition, are they metabolically active?

Most of the studies conducted in the laboratory conditions were performed under nutrient-rich conditions (Lauchnor et al., 2013), whereas in practical applications, such as soil reinforcement, metal remediation in industrial waste streams, and crack repair in concrete, these conditions are quite rare. It is not clear how cells react to nutrient-deficient environments and whether they continue the carbonate precipitation.

In the case of carbon capture sequestration (CCS), the pressure can be very high. The injection and storage of supercritical $\mathrm{CO}_{2}$ into underground geological formation require a minimum pressure at $8 \mathrm{MPa}$ (Martin et al., 2013). Most of the bacteria used in the MCP are cultured under ambient pressure (McCutcheon et al., 2014; Okyay and Rodrigues, 2015). Even though several studies have been conducted at a relatively high pressure at $7.5 \mathrm{MPa}$ (Cunningham et al., 2013; Mitchell et al., 2013), it is still below the minimum requirement for the geological storage of $\mathrm{CO}_{2}$. In the experiment, it took 29 days for the system to gradually pressurize to $7.5 \mathrm{MPa}$ (Mitchell et al., 2013), which is not always realistic in the application. It is reported that high pressures significantly inhibit DNA replication and protein synthesis, therefore suppressing the metabolic functions and growth of mesophilic organisms, including S. pasteurii (Abe et al., 1999). There is an urgent need to study the impact of high pressure on the MCP.

Other constraints for the broad application are high salinity, elevated temperature, and diminished light intensity. In deep saline aquifers where carbon capture and storage take place, the salt concentration can be as high as $251 \mathrm{~g} / \mathrm{L}$ (Liu et al., 2012), whereas the salt concentration for growth medium is typically 1000 times lower, between 2.12 and $35 \mathrm{~g} / \mathrm{L}$ (Ramachandran et al., 2001; Dick et al., 2006; Zhu et al., 2015). The aquifer with a salinity of two orders higher than that in the optimal growth condition of bacteria can be very challenging for microorganisms. The challenges faced by MEOR are the limits on the subsurface environment in which temperature reaches up to $100^{\circ} \mathrm{C}$, salinity extends to 9 wt.\%, $\mathrm{pH}$ ranges between 3 and 9 , and pressures goes up to 7000 psi (Ferris and Stehmeier, 1992). Anaerobic and spore-forming microorganisms are preferred under such harsh condition, including genera of the Bacillacae family, such as Bacillus, Sporolactobacillus, Clostridium, Desulfotomaculum, and Sporosarcina (Ferris et al., 1997). In the pulp and paper industries, the temperature of wastewater can be as high as $60^{\circ} \mathrm{C}$ (Habets et al., 2000). In the subsurface $\mathrm{CO}_{2}$ storage site, the temperature is expected to elevate along the depth (Phillips et al., 2012). For example, during the direct sequestration of $\mathrm{CO}_{2}$ in the form of flue gas emitted from power plants, the temperature is around $120^{\circ} \mathrm{C}$ (Kumar et al., 2011); however, the bacteria used in most of the studies are cultured at a temperature between 20 and $37^{\circ} \mathrm{C}$ (Warren et al., 2001; Qian et al., 2010). Whether they can survive or maintain their microbial activities is questionable. In the industrial carbon sequestration, where phototrophs are involved, light intensity is essential for MCP (Kumar et al., 2011). While low light intensity limits the biomass productivity, high light intensity causes photo-inhibition of phototrophic microorganisms (Rubio et al., 2003). However, a uniform distribution of light is less likely in most of the cases.

\section{By-products and Uncontrolled Growth}

Although the MCP excels their comparable "abiotic" application with respect to environmental concerns, it still has a lot of limitations. Toxic ammonium is generated as a by-product during ureolysis (Table 2) and may pose environmental and health risks (De Muynck et al., 2013). To treat the ammonium in groundwater, a higher cost is required.

If incomplete reaction occurs during denitrification, a GHG, such as nitrous oxide, will be produced (Van Paassen et al., 2010). With an atmospheric lifetime of 114 years, $\mathrm{N}_{2} \mathrm{O}$ is a powerful GHG that has a 300-fold greater potential for global warming effects compared with that of $\mathrm{CO}_{2}$ (Alley et al., 2007; Change, 2007).

The involvement of SRB leads to a release of highly toxic and flammable gas $\mathrm{H}_{2} \mathrm{~S}$, which induces various environmental risks and health symptoms (Kfir et al., 2015). Nausea, vomiting, keratoconjunctivitis, and corneal ulceration occur at a concentration of 50-100 ppm of $\mathrm{H}_{2} \mathrm{~S}$. Olfactory nerve endings become rapidly fatigued when exposed to 100-150 ppm. Rhinitis, bronchitis, and pulmonary edema are caused at a concentration of 200-300 ppm. Cardiopulmonary arrest appears when the concentration is higher than $700 \mathrm{ppm}$. Unconsciousness and death are serious outcomes at the concentration above $1000 \mathrm{ppm}$.

Another concern with the MCP biotechnology is the uncontrolled growth of microorganisms. For example, Bacillus bacteria may form endospores that can lead to uncontrolled growth (Dei and Chelazzi, 2013). On the other hand, nutrients introduced during the process or organic matters produced by phototrophs can support the growth of environmental microbes, such as airborne fungi (Perito et al., 2014).

\section{Challenges in the Upscaled Engineering}

Successful field implementation of remediation techniques requires upscaling of the systems at the laboratory scale to the field or geological scale. Biomass needs to be produced in an enormous amount, a gigantic bioreactor has to be built in order to consume a large amount of $\mathrm{CO}_{2}$, and designs of wells are necessary to inject chemicals/nutrients/cultures into complicated systems. Due to the site-specific conditions and heterogeneous distribution in the field, uniform treatment is harder to be obtained.

Unlike experimental conditions where most parameters can be controlled, more variables in field studies need to be monitored during the application. These variables include microbial consortia or their succession, solution chemistry, and available electron donors. However, to install or design the monitoring system is a tough task not only because of the geological accessibility but also due to the heterogeneous distributions.

\section{Upscaling Bioreactors}

Laboratory experiments are typically carried out in a 2- to 5 - $\mathrm{L}$ chemostat, whereas the size of the bioreactor for the field 
TABLE 2 | Bacterial species, their metabolic pathways, and possible challenges faced by them in different industrial applications.

\begin{tabular}{|c|c|c|c|c|}
\hline Application & Challenge for bacteria & Bacteria & Metabolic pathway & Reference \\
\hline $\begin{array}{l}\text { Filler for rubber, } \\
\text { plastic, and ink }\end{array}$ & & $\begin{array}{l}\text { Geobacillus } \\
\text { thermoglucosidasius }\end{array}$ & - & Yoshida et al. (2010) \\
\hline $\begin{array}{l}\text { Metal and } \\
\text { radionuclide } \\
\text { remediation }\end{array}$ & $\begin{array}{l}\text { Toxicity of highly } \\
\text { concentrated heavy metal } \\
\text { Radioactivity }\end{array}$ & $\begin{array}{l}\text { Kocuria flava } \\
\text { Lysinibacillus sphaericus } \\
\text { Sporosarcina ginsengisoli } \\
\text { Bacillus cereus } \\
\text { Sporosarcina pasteurii }\end{array}$ & $\begin{array}{l}\text { Ureolysis } \\
\text { Ureolysis } \\
\text { Ureolysis } \\
\text { Ureolysis } \\
\text { Ureolysis }\end{array}$ & $\begin{array}{l}\text { Achal et al. (2011b) } \\
\text { Kang et al. (2014) } \\
\text { Achal et al. (2012) } \\
\text { Kumari et al. (2014) } \\
\text { Warren et al. (2001) and Lauchnor et al. (2013) }\end{array}$ \\
\hline $\mathrm{CO}_{2}$ sequestration & High pressure of $\mathrm{CO}_{2}$ & $\begin{array}{l}\text { Spirulina platensis } \\
\text { Chlorella vulgaris } \\
\text { Microbial mat including } \\
\text { cyanobacteria and diatoms }\end{array}$ & $\begin{array}{l}\text { Photosynthesis } \\
\text { Photosynthesis } \\
\text { Photosynthesis }\end{array}$ & $\begin{array}{l}\text { Ramanan et al. (2010) and Kumar et al. (2011) } \\
\text { Ramanan et al. (2010) and Wang et al. (2010) } \\
\text { McCutcheon et al. (2014) }\end{array}$ \\
\hline MEOR & & Sporosarcina pasteurii & Ureolysis & Dejong et al. (2006) \\
\hline $\begin{array}{l}\text { Soil and } \\
\text { geological } \\
\text { formation } \\
\text { reinforcement }\end{array}$ & $\begin{array}{l}\text { Oxic to anoxic condition } \\
\text { Unique high pressure }\end{array}$ & $\begin{array}{l}\text { Castellaniella denitrificans } \\
\text { Sporosarcina pasteurii } \\
\text { Halomonas halodenitrificans } \\
\text { Shewanella frigidimarina }\end{array}$ & $\begin{array}{l}\text { Denitrification } \\
\text { Ureolysis } \\
\text { Denitrification } \\
\text { - }\end{array}$ & $\begin{array}{l}\text { Van Paassen et al. (2010) } \\
\text { Dejong et al. (2006), Whiffin et al. (2007), Harkes et al. } \\
\text { (2010), Chu et al. (2012), and Martinez et al. (2013) } \\
\text { Martin et al. (2013) } \\
\text { Mitchell et al. (2009) }\end{array}$ \\
\hline $\begin{array}{l}\text { Limestone } \\
\text { restoration }\end{array}$ & & $\begin{array}{l}\text { Myxococcus xanthus } \\
\text { Bacillus cereus } \\
\text { Sporosarcina pasteurii } \\
\text { Bacillus subtilis } \\
\text { Bacillus sphaericus } \\
\text { Pseudomonas putida } \\
\text { Bacillus lentus } \\
\text { Micrococcus sp. } \\
\text { Pseudomonas } \\
\text { Acinetobacter }\end{array}$ & $\begin{array}{l}\text { Ammonification } \\
\text { Ureolysis/denitrification } \\
\text { Ureolysis } \\
\text { Ureolysis } \\
\text { Ureolysis } \\
\text { Ureolysis } \\
\text { Ureolysis } \\
\text { - } \\
\text { - } \\
\text { - }\end{array}$ & $\begin{array}{l}\text { Rodriguez-Navarro et al. (2003), Chekroun et al. (2004), } \\
\text { and González-Muñoz et al. (2010) } \\
\text { Castanier et al. (2000) } \\
\text { De Muynck et al. (2013) } \\
\text { Tiano et al. (1999) } \\
\text { Dick et al. (2006) } \\
\text { May (2005) } \\
\text { Dick et al. (2006) } \\
\text { Tiano et al. (1999) } \\
\text { Zamarreno et al. (2009) } \\
\text { Zamarreno et al. (2009) }\end{array}$ \\
\hline $\begin{array}{l}\text { Concrete } \\
\text { restoration }\end{array}$ & $\begin{array}{l}\text { High pH, desiccation, } \\
\text { nutrient deficiency }\end{array}$ & $\begin{array}{l}\text { Sporosarcina pasteurii } \\
\text { Bacillus sphaericus } \\
\text { Bacillus pseudofirmus } \\
\text { Bacillus cohnii } \\
\text { Synechococcus }\end{array}$ & $\begin{array}{l}\text { Ureolysis } \\
\text { Ureolysis } \\
\text { Ureolysis } \\
\text { Ureolysis } \\
\text { Photosynthesis }\end{array}$ & $\begin{array}{l}\text { Kim et al. (2009) and Bang et al. (2010) } \\
\text { De Belie and De Muynck (2009) } \\
\text { Jonkers et al. (2010) } \\
\text { Jonkers et al. (2010) } \\
\text { Zhu et al. (2015) }\end{array}$ \\
\hline
\end{tabular}

application is several orders of laboratory scale. Therefore, a large volume of nutrients and cultures is required in the industrial application of MCP. Nevertheless, challenges exist not only in producing and transporting the bulky medium and bacterial solution but also in the technical difficulties related to bioreactors. In the treatment of groundwater, possible precipitation can occur in the tubing outside of the reactor or it can be trapped on the filters, resulting in clogging the system (Lauchnor et al., 2013). The case of the waste water treatment shows that the functionality of bioreactors is not well understood, thus the performance of bioreactors is difficult to predict and control (Herrero and Stuckey, 2014). An evenly and efficiently distributed light source is hard to obtain in the photobioreactor for $\mathrm{CO}_{2}$ sequestration (Kumar et al., 2011).

The economic concern is another limitation for direct transfer of the laboratory experiments to the field application. For fundamental research in laboratory, analytical chemicals, the highest grade of nutrients, and axenic culture are necessary (Dhami et al., 2013; Silva et al., 2015). However, the use of these expensive materials in the industrial application will result in an extremely high cost.

\section{Injection of Chemicals, Nutrients, and Cultures}

To ensure the beneficial microbial activities, sufficient nutrients and chemicals need to be supplied. However, the nutrients and chemicals can quickly be depleted due to (1) the rates of flowing through being too fast for reactions to occur, (2) nutrients not being supplied in a sufficient amount, and/or (3) nutrients being used up over time (Dejong et al., 2014).

The depletion rate of nutrients, chemicals, and cultures is a key problem for the calculation of the initial injection amount, and the following amendment injection. Even if nutrients and cultures are supplied in an optimal amount, a restricted transportation can occur due to the extensive precipitation and plugging near the injection well (Fujita et al., 2008). On the other hand, a large amount of incomplete usage of chemicals has been observed after the first flow-through of the column in the laboratory scale. To make it more sustainable, these chemicals can be recycled through the columns after the first injection. However, recirculating the chemicals and nutrients in the field application is confronting technical difficulties. Due to biomineralization, bacteria can die-off or be covered by carbonates overtime, thus becoming inactivated (Cuthbert et al., 2012). Therefore, to seal 
large voids, such as porous media or rock fractures, additional injections of bacteria are required.

\section{Obtaining Uniform Treatment}

The precipitation of carbonates is highly impacted by the solution chemistry and microbial activities. Whether it is in groundwater, oil reservoir, soil and geological formation, spatial heterogeneity is expected regarding to solution chemistry, transport, pore distribution, and biodiversity (Dejong et al., 2010). The availability of chemicals, nutrients, and microbes depends upon the fluid movement and transport. Therefore, it is quite challenging to obtain a uniform treatment in the real application.

In the case of groundwater, the injected solution is diluted through the pathway from the injection site to downstream. In the case of soil and geological formation, rapid precipitation occurs around the injection site, plugging the adjacent pores and resulting in blocking the solution to further transport. A field test to improve the geotechnical properties of soil via MCP showed a non-uniform cementation distribution at the initial stage of injection (Dejong et al., 2014).

\section{Monitoring}

To ensure the high performance and efficiency of the MCP in the field application, parameters such as solution chemistry, microbial activities, and, especially, carbonate production should be monitored. Ion concentrations of the fluid extracted from the bioreactor or column need to be measured to calculate the concentration of calcium and carbonate species; microbial densities are required to be counted to ensure the effectiveness of microbial activities; and solid samples need to be analyzed to calculate the amount of carbonate precipitated as well as their ratio to the adjacent particles. In contrast to the laboratory experiments, parameters, including temperature, pressure, solution chemistry, and microbial communities, vary greatly in the field application. Located in the subsurface, sampling sites are not easily approachable. Therefore, designing monitoring wells and systems are of great challenge.

\section{STRATEGIES TO OVERCOME THE LIMITATION IN MCP-BASED BIOREMEDIATION TECHNIQUES}

\section{Regarding Microbial Cells Limitation Mitigating Extreme Conditions}

Here, we are going to discuss the strategies and methods for overcoming the challenges of bioremediation techniques (Figure 6), which were listed in Section "Challenges in MCP Biotechnology." Bacteria found in natural environment, of which the condition is comparable to that of the field application, can be considered as candidates for MCP. Alternatively, conditions of the field site can be amended to favor the growth of microorganisms being used in the application.

One strategy to mitigate the drying problem is to adopt desiccation-resistant bacteria, which typically form spores (Jonkers and Schlangen, 2009). Another solution is to simultaneously apply protective materials, such as polyurethane and silica gel to immobilize cells (Bang et al., 2001; Kim et al., 2009). Similar materials have been applied to protect bacteria from high $\mathrm{pH}$. In other studies, Cyclic EnRiched Ureolytic Powder and Activated Compact Denitrifying Core are used (Erşan et al., 2015a).

To ensure the viability of aerobic bacteria under anaerobic conditions, air can be injected into the remediation site. However, it is a costly and complicated process. Alternatively, anaerobic denitrifiers offer advantages over ureolytic bacteria by taking nitrate as an oxidant (Martin et al., 2013). Anoxygenic photosynthetic microorganisms, such as Rhodopseudomonas palustris, that stimulate the precipitation of calcite can be a good candidate to solve this problem as well (Bosak et al., 2007).

Among the few researchers who have conducted the experiments in low nutrient environment, Erşan et al. (2015b) demonstrated that denitrification strains (Pseudomonas aeruginosa and Diaphorobacter nitroreducens) were able to precipitate carbonate; in another study, an autotrophic strain of Synechococcus has been showed to promote calcification on the concrete surface (Zhu et al., 2015). In addition, a variety of picocyanobacteria demonstrated to stimulate carbonate precipitation in oligotrophic environments (Dittrich et al., 2004; Liu et al., 2010).

Pressure-resistant bacteria are preferred to repair the fractures in the capping rocks. One study using the pressure close to the actual situation of CCS has been conducted so far (Martin et al., 2013). It found that Halomonas halodenitrificans can grow under a pressure of $20 \mathrm{MPa}$, and it is suitable for such application (Martin et al., 2013). Compared with the ambient pressure, the rate of calcium removal by $H$. halodenitrificans was not reduced at $8 \mathrm{MPa}$. The biofilm of $B$. mojavensis was found to grow in Berea sandstone cores under $8.9 \mathrm{MPa}$ and $32^{\circ} \mathrm{C}$ (Mitchell et al., 2008). Under the condition of $50-80^{\circ} \mathrm{C}$ and 271 atm with supercritical $\mathrm{CO}_{2}$, spore-forming organisms, such as $B$. subtilis, $B$. cereus, and B. pumilus, showed a $0.58-3 \log _{10}$ reduction in viability over a 4-h period (Zhang et al., 2006). Similarly, S. pasteurii were reported to maintain viability at a pressure of $7.5 \mathrm{MPa}$ (Mitchell et al., 2013). Deep-sea microorganisms, such as barophiles, are possible candidates, with their ability to survive under extreme pressure conditions (Abe et al., 1999). Research on mesoscale high-pressure experiments and modeling toward the field-scale implementation is being undertaken (Phillips et al., 2012).

In the field application where hypersaline aquifer is present, microorganisms growing in highly saline environments can be considered. It is reported that $S$. pasteurii can sustain salinities up to $58 \mathrm{~g} / \mathrm{L}$ (Kuhlmann and Bremer, 2002), and they were able to increase $\mathrm{pH}$ and speed up the carbonate precipitation within the range of 5.8-35 g/L (Dupraz et al., 2009b). In the bioengineering projects under high temperature, strains isolated from hot springs (Fouke, 2011; Okumura et al., 2013) can be considered to increase the carbonate precipitation.

\section{Diminishing Undesired By-products}

To mitigate the undesired by-products, several solutions can be adopted: (1) find alternative strategies to avoid the generation of these secondary products, (2) use the by-products for other applications nearby, and (3) adopt treatments to dismiss the by-products.

To avoid the generation of undesired by-products, alternative techniques based on microbial cells can be adopted for carbonate 
precipitation. For example, biomineralization takes place on cell walls or EPS serving as a nucleation template, or alternative metabolic activities, such as photosynthesis and denitrification, which do not result in undesired end-products, offer viable options.

In the case of denitrification, toxic intermediate products can be avoided by ensuring the completeness of reactions. The generated by-products can be repurposed in other applications. For example, ammonia released from ureolysis and ammonification can be used in the fertilizer (De Jong et al., 2013).

A third solution is to treat the generated by-products after the application is done. Biological reactors with microbial consortia have been applied to treat wastewater, including ammonia (Grady and Filipe, 2000; Herrero and Stuckey, 2014).

\section{Control the Growth of Bacteria}

Strategies need to be taken to control the growth of introduced or augmented bacteria. One solution is to control the source by using inactive cells, such as killed or freeze-dried microorganisms. Spore-forming bacteria can survive longer; therefore, they are less preferable in this aspect. Another solution is to limit the availability of nutrients after application and lead to the die-off of bacteria.

\section{Toward Engineering Technologies \\ Bioreactor}

To improve the functionality of the bioreactors, both viability of microorganisms and mechanical performance of the system have to be ensured. Parameters such as temperature, $\mathrm{pH}$, cell density, pressure, and, in some cases, light intensity are essential factors for microbial activities. Higher surface area-to-volume ratio, well mixing, scalability, and ease of operation are crucial features to improve the bioreactor systems (Kumar et al., 2011). In the case of carbon sequestration, $\mathrm{SO}_{\mathrm{x}}$ and $\mathrm{NO}_{\mathrm{x}}$, critical $\mathrm{CO}_{2}$ concentration and $\mathrm{O}_{2}$ accumulation should be considered.

To decrease the cost of the real application, nutrients and cells are not necessarily of the same purity grade as those in the laboratory. For example, corn steep liquor and lactose mother liquor can be economical alternatives of medium ingredients to lower the cost (Achal et al., 2009, 2010). To avoid the high cost due to the use of pure bacterial cultures, approaches with mixed or nonaxenic bacterial cultures should be developed (Silva et al., 2015).

\section{Injection Designs}

By controlling key field parameters such as concentrations of chemicals, flow rates and amendment injection (Lauchnor et al., 2013), and distribution of injection wells with a deliberate pattern (De Jong et al., 2013), an optimal injection strategy can be achieved. Compared with continuous injection, pulsed injection reduced the accumulation of localized mineral plugging, and resulted in a more efficient precipitation of calcium and strontium (Lauchnor et al.,
2013). Combined with a controlled flow rate, the pulsed injection can control the distribution of precipitation without extensive plugging of the transport channels. The transportation efficiency can also be improved by designing a pattern of injection wells according to the morphology and property of the remediation site. With further studies on optimizing injection strategies, including single- versus multiple-phase injections, surficial flooding versus deep injection, and high-concentration versus low-concentration treatments (De Jong et al., 2013), it will be possible to develop an ideal injection design for the field-scale applications.

\section{Obtaining Uniform Treatment}

The original non-uniform formation subsurface structure makes it challenging to obtain a homogeneous treatment with MCP. By modifying injection patterns and changing flow directions, it is possible to improve the efficiency. For example, by adopting an injection pattern with five-spot wells, and injected fluids in opposite directions, a relatively uniform treatment was achieved in the field application (Dejong et al., 2014). In addition, bacteria in nutrient solution were re-circulated resembling a large-scale chemostat, which keeps a uniform distribution of highly active microbes. Other parameters, such as solution viscosity and density, and microbe size relative to soil pore throat size can be managed to optimize the treatment.

\section{Monitoring}

The monitoring of the MCP in the field application is challenging mostly due to the inaccessibility of sampling sites. Remote sensing and an automatic system can be possible solutions. Soil properties of the remediated site can be obtained through remote sensing, and a map showing spatial variability will be produced. Another approach can be installing an automatic sampling and analyzing system, coupled with a quality-control program.

\section{AUTHOR CONTRIBUTIONS}

$\mathrm{TZ}$ and $\mathrm{MD}$ have contributed to the manuscript equally, reviewed the literature and organized the structure of the manuscript, and wrote the manuscript and approved the final version to be published.

\section{ACKNOWLEDGMENTS}

We acknowledge the National Sciences and Engineering Research Council of Canada (Discovery grant to Maria Dittrich) and the Ontario Trillium Scholarship to Tingting Zhu for the funding of this research. The authors acknowledge the editorial suggestions by Jennifer Krissilas.

\section{REFERENCES}

Abe, F., Kato, C., and Horikoshi, K. (1999). Pressure-regulated metabolism in microorganisms. Trends Microbiol. 7, 447-453. doi:10.1016/S0966-842X(99)01608-X

Achal, V., and Mukherjee, A. (2015). A review of microbial precipitation for sustainable construction. Constr. Build. Mater. 93, 1224-1235. doi:10.1016/j. conbuildmat.2015.04.051

Achal, V., Mukherjee, A., Basu, P. C., and Reddy, M. S. (2009). Lactose mother liquor as an alternative nutrient source for microbial concrete production by Sporosarcina pasteurii. J. Ind. Microbiol. Biotechnol. 36, 433-438. doi:10.1007/ s10295-008-0514-7

Achal, V., Mukherjee, A., and Reddy, M. S. (2010). Biocalcification by Sporosarcina pasteurii using corn steep liquor as the nutrient source. Ind. Biotechnol. 6, 170-174. doi:10.1089/ind.2010.6.170 
Achal, V., Mukherjee, A., and Reddy, M. S. (2011a). Effect of calcifying bacteria on permeation properties of concrete structures. J. Ind. Microbiol. Biotechnol. 38, 1229-1234. doi:10.1007/s10295-010-0901-8

Achal, V., Pan, X., and Zhang, D. (2011b). Remediation of copper-contaminated soil by Kocuria flava CR1, based on microbially induced calcite precipitation. Ecol. Eng. 37, 1601-1605. doi:10.1016/j.ecoleng.2011.06.008

Achal, V., Pan, X., Fu, Q., and Zhang, D. (2012). Biomineralization based remediation of As (III) contaminated soil by Sporosarcina ginsengisoli. J. Hazard. Mater. 201, 178-184. doi:10.1016/j.jhazmat.2011.11.067

Ahluwalia, S. S., and Goyal, D. (2007). Microbial and plant derived biomass for removal of heavy metals from wastewater. Bioresour. Technol. 98, 2243-2257. doi:10.1016/j.biortech.2005.12.006

AïTcin, P.-C. (2000). Cements of yesterday and today: concrete of tomorrow. Cem. Concr. Res. 30, 1349-1359. doi:10.1016/S0008-8846(00)00365-3

Alley, R., Berntsen, T., Bindoff, N. L., Chen, Z., Chidthaisong, A., Friedlingstein, P., et al. (2007). "Summary for policymakers," in Intergovernmental Panel on Climate Change: Climate change 2007: the physical science basis. Contribution of Working Group I to the Fourth Assessment Report of the Intergovernmental Panel on Climate Change. eds S. Solomon, D. Qin, and M. Manning (Cambridge and New York: Cambridge University Press). Available at: www.ipcc.ch/ipccreports/ ar4-wg1.htm

Aloisi, G., Gloter, A., Krüger, M., Wallmann, K., Guyot, F., and Zuddas, P. (2006). Nucleation of calcium carbonate on bacterial nanoglobules. Geology 34, 1017-1020. doi:10.1130/G22986A.1

Altermann, W., Kazmierczak, J., Oren, A., and Wright, D. T. (2006). Cyanobacterial calcification and its rock-building potential during 3.5 billion years of earth history. Geobiology 4, 147-166. doi:10.1111/j.1472-4669.2006.00076.x

Anderson, S., Appanna, V. D., Huang, J., and Viswanatha, T. (1992). A novel role for calcite in calcium homeostasis. FEBS Lett. 308, 94-96. doi:10.1016/0014-5793(92)81059-U

Andrews, J. E., Riding, R., and Dennis, P. F. (1997). The stable isotope record of environmental and climatic signals in modern terrestrial microbial carbonates from Europe. Palaeogeogr. Palaeoclimatol. Palaeoecol. 129, 171-189. doi:10.1016/S0031-0182(96)00120-4

Arp, G., Reimer, A., and Reitner, J. (1999). Calcification in cyanobacterial biofilms of alkaline salt lakes. Eur. J. Phycol. 34, 393-403. doi:10.1080/0967026991000 1736452

Arp, G., Reimer, A., and Reitner, J. (2001). Photosynthesis-induced biofilm calcification and calcium concentrations in Phanerozoic oceans. Science 292, 1701-1704. doi:10.1126/science.1057204

Badger, M. R., and Price, G. D. (1992). The $\mathrm{CO}_{2}$ concentrating mechanism in cyanobacteria and microalgae. Physiol. Plant. 84, 606-615. doi:10.1034/j.1399-3054.1992.840416.x

Bang, S. S., Galinat, J. K., and Ramakrishnan, V. (2001). Calcite precipitation induced by polyurethane-immobilized Bacillus pasteurii. Enzyme Microb. Technol. 28, 404-409. doi:10.1016/S0141-0229(00)00348-3

Bang, S. S., Lippert, J. J., Yerra, U., Mulukutla, S., and Ramakrishnan, V. (2010). Microbial calcite, a bio-based smart nanomaterial in concrete remediation. Int. J. Smart Nano Mater. 1, 28-39. doi:10.1080/19475411003593451

Banks, E. D., Taylor, N. M., Gulley, J., Lubbers, B. R., Giarrizo, J. G., Bullen, H. A., et al. (2010). Bacterial calcium carbonate precipitation in cave environments: a function of calcium homeostasis. Geomicrobiol. J. 27, 444-454. doi:10.1080/01490450903485136

Baumgartner, L. K., Dupraz, C., Buckley, D. H., Spear, J. R., Pace, N. R., and Visscher, P. T. (2009). Microbial species richness and metabolic activities in hypersaline microbial mats: insight into biosignature formation through lithification. Astrobiology 9, 861-874. doi:10.1089/ast.2008.0329

Baumgartner, L. K., Reid, R. P., Dupraz, C., Decho, A. W., Buckley, D., Spear, J., et al. (2006). Sulfate reducing bacteria in microbial mats: changing paradigms, new discoveries. Sediment. Geol. 185, 131-145. doi:10.1016/j.sedgeo.2005.12.008

Belliveau, B., Starodub, M., and Trevors, J. (1991). Occurrence of antibiotic and metal resistance and plasmids in Bacillus strains isolated from marine sediment. Can. J. Microbiol. 37, 513-520. doi:10.1139/m91-087

Benini, S., Rypniewski, W. R., Wilson, K. S., Miletti, S., Ciurli, S., and Mangani, S. (1999). A new proposal for urease mechanism based on the crystal structures of the native and inhibited enzyme from Bacillus pasteurii: why urea hydrolysis costs two nickels. Structure 7, 205-216. doi:10.1016/S0969-2126(99)80026-4

Beveridge, T., and Murray, R. (1976). Uptake and retention of metals by cell walls of Bacillus subtilis. J. Bacteriol. 127, 1502-1518.
Boetius, A., Ravenschlag, K., Schubert, C. J., Rickert, D., Widdel, F., Gieseke, A., et al. (2000). A marine microbial consortium apparently mediating anaerobic oxidation of methane. Nature 407, 623-626. doi:10.1038/35036572

Boquet, E., Boronat, A., and Ramos-Cormenzana, A. (1973). Production of calcite (calcium carbonate) crystals by soil bacteria is a general phenomenon. Nature 246, 527-529. doi:10.1038/246527a0

Bosak, T., Greene, S., and Newman, D. (2007). A likely role for anoxygenic photosynthetic microbes in the formation of ancient stromatolites. Geobiology 5, 119-126. doi:10.1111/j.1472-4669.2007.00104.x

Bosak, T., and Newman, D. K. (2003). Microbial nucleation of calcium carbonate in the Precambrian. Geology 31, 577-580. doi:10.1130/0091-7613(2003)031<0577:MNOCCI>2.0.CO;2

Bosscher, H., and Schlager, W. (1993). Accumulation rates of carbonate platforms. J. Geol. 101, 345-355. doi:10.1086/648228

Braissant, O., Decho, A. W., Dupraz, C., Glunk, C., Przekop, K. M., and Visscher, P. T. (2007). Exopolymeric substances of sulfate-reducing bacteria: interactions with calcium at alkaline $\mathrm{pH}$ and implication for formation of carbonate minerals. Geobiology 5, 401-411. doi:10.1111/j.1472-4669.2007.00117.x

Brookshaw, D., Pattrick, R., Lloyd, J., and Vaughan, D. (2012). Microbial effects on mineral-radionuclide interactions and radionuclide solid-phase capture processes. Mineral. Mag. 76, 777-806. doi:10.1180/minmag.2012.076.3.25

Cailleau, G., Braissant, O., and Verrecchia, E. P. (2004). Biomineralization in plants as a long-term carbon sink. Naturwissenschaften 91, 191-194. doi:10.1007/ s00114-004-0512-1

Cañveras, C., Sanchez-Moral, S., Sloer, V., and Saiz-Jimenez, C. (2001). Microorganisms and microbially induced fabrics in cave walls. Geomicrobiol. J. 18, 223-240. doi:10.1080/01490450152467769

Castanier, S., Le Metayer-Levrel, G., Orial, G., Loubiere, J. F., and Perthuisot, J. P. (2000). "Bacterial carbonatogenesis and applications to preservation and restoration of historic property," in Of Microbes and Art: The Role of Microbial Communities in the Degradation and Protection of Cultural Heritage. eds O. Ciferri, P. Le Tiano, and G. Mastromei (New York: Springer), 203-218 .

Castanier, S., Le Metayer-Levrel, G., and Perthuisot, J. P. (1999). Ca-carbonates precipitation and limestone genesis - the microbiogeologist point of view. Sediment. Geol. 126, 9-23. doi:10.1016/S0037-0738(98)00144-4

Change, I. P. O. C. (2007). Climate change 2007: the physical science basis. Agenda 6,333 .

Chekroun, K. B., Rodríguez-Navarro, C., González-Muñoz, M. T., Arias, J. M., Cultrone, G., and Rodríguez-Gallego, M. (2004). Precipitation and growth morphology of calcium carbonate induced by Myxococcus xanthus: implications for recognition of bacterial carbonates. J. Sediment. Res. 74, 868-876. doi:10.1306/050504740868

Chou, C.-W., Seagren, E. A., Aydilek, A. H., and Lai, M. (2011). Biocalcification of sand through ureolysis. J. Geotech. Geoenviron. Eng. 137, 1179-1189. doi:10.1061/(ASCE)GT.1943-5606.0000532

Chu, J., Stabnikov, V., and Ivanov, V. (2012). Microbially induced calcium carbonate precipitation on surface or in the bulk of soil. Geomicrobiol. J. 29, 544-549. doi:10.1080/01490451.2011.592929

Cunningham, A., Gerlach, R., Spangler, L., and Mitchell, A. (2009). Microbially enhanced geologic containment of sequestered supercritical $\mathrm{CO}_{2}$. Energy Procedia 1, 3245-3252. doi:10.1016/j.egypro.2009.02.109

Cunningham, A. B., Lauchnor, E., Eldring, J., Esposito, R., Mitchell, A. C., Gerlach, R., et al. (2013). Abandoned well $\mathrm{CO}_{2}$ leakage mitigation using biologically induced mineralization: current progress and future directions. Greenhouse Gases Sci. Technol. 3, 40-49. doi:10.1002/ghg.1331

Curti, E. (1999). Coprecipitation of radionuclides with calcite: estimation of partition coefficients based on a review of laboratory investigations and geochemical data. Appl. Geochem. 14, 433-445. doi:10.1016/S0883-2927(98)00065-1

Cuthbert, M. O., Riley, M. S., Handley-Sidhu, S., Renshaw, J. C., Tobler, D. J., Phoenix, V. R., et al. (2012). Controls on the rate of ureolysis and the morphology of carbonate precipitated by $S$. pasteurii biofilms and limits due to bacterial encapsulation. Ecol. Eng. 41, 32-40. doi:10.1016/j.ecoleng.2012.01.008

De Belie, N., and De Muynck, W. (2009). "Crack repair in concrete using biodeposition," in Proceedings of the International Conference on Concrete Repair, Rehabilitation and Retrofitting (ICCRRR) (Cape Town), 291-292.

De Jong, J., Soga, K., Kavazanjian, E., Burns, S., Van Paassen, L., Al Quabany, A., et al. (2013). Biogeochemical processes and geotechnical applications: progress, opportunities and challenges. Geotechnique 63, 287-301. doi:10.1680/geot. SIP13.P.017 
De Muynck, W., Cox, K., De Belie, N., and Verstraete, W. (2008a). Bacterial carbonate precipitation as an alternative surface treatment for concrete. Constr. Build. Mater. 22, 875-885. doi:10.1016/j.conbuildmat.2006.12.011

De Muynck, W., Debrouwer, D., De Belie, N., and Verstraete, W. (2008b). Bacterial carbonate precipitation improves the durability of cementitious materials. Cem. Concr. Res. 38, 1005-1014. doi:10.1016/j.cemconres.2008.03.005

De Muynck, W., De Belie, N., and Verstraete, W. (2010). Microbial carbonate precipitation in construction materials: a review. Ecol. Eng. 36, 118-136. doi:10.1016/j.ecoleng.2009.02.006

De Muynck, W., Verbeken, K., De Belie, N., and Verstraete, W. (2013). Influence of temperature on the effectiveness of a biogenic carbonate surface treatment for limestone conservation. Appl. Microbiol. Biotechnol. 97, 1335-1347. doi:10.1007/s00253-012-3997-0

De Philippis, R., Sili, C., Paperi, R., and Vincenzini, M. (2001). Exopolysaccharideproducing cyanobacteria and their possible exploitation: a review. J. Appl. Phycol. 13, 293-299. doi:10.1023/A:1017590425924

Dei, L., and Chelazzi, D. (2013). "Biomineralization, geopolymers and hybrid nanocomposites," in Nanoscience for the Conservation of Works of Art. eds P. Baglioni and D. Chelazzi (Cambridge: The Royal Society of Chemistry), 372-395. doi:10.1039/9781849737630-00372

Dejong, J., Martinez, B., Ginn, T., Hunt, C., Major, D., and Tanyu, B. (2014). Development of a scaled repeated five-spot treatment model for examining microbial induced calcite precipitation feasibility in field applications. Geotech. Test. J. 37, 424-435. doi:10.1520/GTJ20130089

Dejong, J. T., Fritzges, M. B., and Nüsslein, K. (2006). Microbially induced cementation to control sand response to undrained shear. J. Geotech. Geoenviron. Eng. 132, 1381-1392. doi:10.1061/(ASCE)1090-0241(2006)132:11(1381)

Dejong, J. T., Mortensen, B. M., Martinez, B. C., and Nelson, D. C. (2010). Bio-mediated soil improvement. Ecol. Eng. 36, 197-210. doi:10.1016/j. ecoleng.2008.12.029

Dhami, N. K., Reddy, M. S., and Mukherjee, A. (2013). Biomineralization of calcium carbonates and their engineered applications: a review. Front. Microbiol. 4:314. doi:10.3389/fmicb.2013.00314

Dick, J., De Windt, W., De Graef, B., Saveyn, H., Van Der Meeren, P., De Belie, N., et al. (2006). Bio-deposition of a calcium carbonate layer on degraded limestone by Bacillus species. Biodegradation 17, 357-367. doi:10.1007/ s10532-005-9006-x

Dittrich, M., Kurz, P., and Wehrli, B. (2004). The role of autotrophic picocyanobacteria in calcite precipitation in an oligotrophic lake. Geomicrobiol. J. 21, 45-53. doi:10.1080/01490450490253455

Dittrich, M., and Obst, M. (2004). Are picoplankton responsible for calcite precipitation in lakes? Ambio 33, 559-564. doi:10.1579/0044-7447-33.8.559

Dittrich, M., and Sibler, S. (2005). Cell surface groups of two picocyanobacteria strains studied by zeta potential investigations, potentiometric titration, and infrared spectroscopy. J. Colloid Interface Sci. 286, 487-495. doi:10.1016/j. jcis.2005.01.029

Dittrich, M., and Sibler, S. (2010). Calcium carbonate precipitation by cyanobacterial polysaccharides. Geol. Soc. Spec. Publ. 336, 51-63. doi:10.1144/ SP336.4

Dupraz, C., Reid, R. P., Braissant, O., Decho, A. W., Norman, R. S., and Visscher, P. T. (2009a). Processes of carbonate precipitation in modern microbial mats. Earth Sci. Rev. 96, 141-162. doi:10.1016/j.earscirev.2008.10.005

Dupraz, S., Ménez, B., Gouze, P., Leprovost, R., Bénézeth, P., Pokrovsky, O. S., et al. (2009b). Experimental approach of $\mathrm{CO}_{2}$ biomineralization in deep saline aquifers. Chem. Geol. 265, 54-62. doi:10.1016/j.chemgeo.2008.12.012

Dupraz, C., and Visscher, P. T. (2005). Microbial lithification in marine stromatolites and hypersaline mats. Trends Microbiol. 13, 429-438. doi:10.1016/j. tim.2005.07.008

Dupraz, C., Visscher, P. T., Baumgartner, L. K., and Reid, R. P. (2004). Microbe-mineral interactions: early carbonate precipitation in a hypersaline lake (Eleuthera Island, Bahamas). Sedimentology 51, 745-765. doi:10.1111/j.1365-3091.2004.00649.x

Dworkin, M. (1993). Myxobacteria. Minneapolis: University of Minnesota. doi:10.1002/9780470015902.a0020391

Ehrlich, H. L. (1996). Geomicrobiology. New York, NY: Marcel Dekker.

Erşan, Y. Ç., Da Silva, F. B., Boon, N., Verstraete, W., and De Belie, N. (2015a). Screening of bacteria and concrete compatible protection materials. Constr. Build. Mater. 88, 196-203. doi:10.1016/j.conbuildmat.2015.04.027
Erşan, Y. Ç., De Belie, N., and Boon, N. (2015b). Microbially induced $\mathrm{CaCO}_{3}$ precipitation through denitrification: an optimization study in minimal nutrient environment. Biochem. Eng. J. 101, 108-118. doi:10.1016/j.bej.2015.05.006

Espie, G. S., and Kandasamy, R. A. (1992). Na+-independent HCO3-transport and accumulation in the cyanobacterium Synechococcus UTEX 625. Plant Physiol. 98, 560-568. doi:10.1104/pp.98.2.560

Fein, J. B. (2006). Thermodynamic modeling of metal adsorption onto bacterial cell walls: current challenges. Adv. Agron. 90, 179-202. doi:10.1016/ S0065-2113(06)90005-4

Fein, J. B., Daughney, C. J., Yee, N., and Davis, T. A. (1997). A chemical equilibrium model for metal adsorption onto bacterial surfaces. Geochim. Cosmochim. Acta 61, 3319-3328. doi:10.1016/S0016-7037(97)00166-X

Ferris, F., Stehmeier, L., Kantzas, A., and Mourits, F. (1997). Bacteriogenic mineral plugging. J. Can. Pet. Technol. 36, 56-61. doi:10.2118/97-09-07

Ferris, F. G., and Stehmeier, L. G. (1992). Bacteriogenic Mineral Plugging. United States Patent 664769.

Field, C. B., and Van Aalst, M. (2014). Climate Change 2014: Impacts, Adaptation, and Vulnerability. IPCC.

Fierer, N., and Jackson, R. B. (2006). The diversity and biogeography of soil bacterial communities. Proc. Natl. Acad. Sci. U.S.A. 103, 626-631. doi:10.1073/ pnas. 0507535103

Finch, A., and Allison, N. (2007). Coordination of Sr and Mg in calcite and aragonite. Mineral. Mag. 71, 539-552. doi:10.1180/minmag.2007.071.5.539

Folk, R. L. (1994). Interaction between bacteria, nannobacteria, and mineral precipitation in hot springs of central Italy. Géographie physique et Quaternaire 48, 233-246. doi:10.7202/033005ar

Fouke, B. W. (2011). Hot-spring systems geobiology: abiotic and biotic influences on travertine formation at Mammoth hot springs, Yellowstone National Park, USA. Sedimentology 58, 170-219. doi:10.1111/j.1365-3091.2010.01209.x

Fratesi, S. E. (2002). Distribution and Morphology of Bacteria and Their Byproducts in Microbial Enhanced Oil Recovery Operations. Mississippi State: Mississippi State University.

Freytet, P., and Plet, A. (1996). Modern freshwater microbial carbonates: the Phormidium stromatolites (tufa-travertine) of southeastern Burgundy (Paris Basin, France). Facies 34, 219-237. doi:10.1007/BF02546166

Freytet, P., and Verrecchia, E. P. (1998). Freshwater organisms that build stromatolites: a synopsis of biocrystallization by prokaryotic and eukaryotic algae. Sedimentology 45, 535-563. doi:10.1046/j.1365-3091.1998.00155.x

Fujita, Y., Ferris, F. G., Lawson, R. D., Colwell, F. S., and Smith, R. W. (2000). Subscribed content calcium carbonate precipitation by ureolytic subsurface bacteria. Geomicrobiol. J. 17, 305-318. doi:10.1080/782198884

Fujita, Y., Redden, G. D., Ingram, J. C., Cortez, M. M., Ferris, F. G., and Smith, R. W. (2004). Strontium incorporation into calcite generated by bacterial ureolysis. Geochim. Cosmochim. Acta 68, 3261-3270. doi:10.1016/j. gca.2003.12.018

Fujita, Y., Taylor, J. L., Gresham, T. L., Delwiche, M. E., Colwell, F. S., McLing, T. L., et al. (2008). Stimulation of microbial urea hydrolysis in groundwater to enhance calcite precipitation. Environ. Sci. Technol. 42, 3025-3032. doi:10.1021/ es702643g

Gadd, G. M. (2010). Metals, minerals and microbes: geomicrobiology and bioremediation. Microbiology 156, 609-643. doi:10.1099/mic.0.037143-0

Garcia-Pichel, F., Johnson, S., Youngkin, D., and Belnap, J. (2003). Small-scale vertical distribution of bacterial biomass and diversity in biological soil crusts from arid lands in the Colorado Plateau. Microb. Ecol. 46, 312-321. doi:10.1007/ s00248-003-1004-0

Gerth, K., Pradella, S., Perlova, O., Beyer, S., and Müller, R. (2003). Myxobacteria: proficient producers of novel natural products with various biological activities - past and future biotechnological aspects with the focus on the genus Sorangium. J. Biotechnol. 106, 233-253. doi:10.1016/j. jbiotec.2003.07.015

Gherman, V. D., Boboescu, I. Z., Pap, B., Kondorosi, É, Gherman, G., and Maróti, G. (2014). An acidophilic bacterial-archaeal-fungal ecosystem linked to formation of ferruginous crusts and stalactites. Geomicrobiol. J. 31, 407-418. doi:10. 1080/01490451.2013.836580

Glunk, C., Dupraz, C., Braissant, O., Gallagher, K. L., Verrecchia, E. P., and Visscher, P. T. (2011). Microbially mediated carbonate precipitation in a hypersaline lake, big pond (Eleuthera, Bahamas). Sedimentology 58, 720-736. doi:10.1111/j.1365-3091.2010.01180.x 
Goh, F., Barrow, K. D., Burns, B. P., and Neilan, B. A. (2010). Identification and regulation of novel compatible solutes from hypersaline stromatolite-associated cyanobacteria. Arch. Microbiol. 192, 1031-1038. doi:10.1007/s00203-010-0634-0

Golubic, S. (1973). "The relationship between blue-green algae and carbonate deposits," in The Biology of the Blue-Green Algae, Chap. 21. eds N. G. Carr and B. A. Whitton (London: Blackwell), 434-472.

Gonsalves, G. M. (2011). Bioconcrete - A Sustainable Substitute for Concrete?. Universitat Politècnica de Catalunya. Institut Universitari de Recerca en Ciència i Tecnologies de la Sostenibilitat.

González-Muñoz, M. T., Rodriguez-Navarro, C., Martínez-Ruiz, F., Arias, J. M., Merroun, M. L., and Rodriguez-Gallego, M. (2010). Bacterial biomineralization: new insights from Myxococcus-induced mineral precipitation. Geol. Soc. Spec. Publ. 336, 31-50. doi:10.1144/SP336.3

Grady, C. Jr., and Filipe, C. (2000). Ecological engineering of bioreactors for wastewater treatment. Water Air Soil Pollution 123, 117-132. doi:10.102 3/A:1005201528411

Grotzinger, J. P., and Knoll, A. H. (1999). Stromatolites in Precambrian carbonates: evolutionary mileposts or environmental dipsticks? Annu. Rev. Earth Planet. Sci. 27, 313-358. doi:10.1146/annurev.earth.27.1.313

Guo, L., Andrews, J., Riding, R., Dennis, P., and Dresser, Q. (1996). Possible microbial effects on stable carbon isotopes in hot-spring travertines. J. Sediment. Res. 66, 468-473. doi:10.1306/D4268379-2B26-11D7-8648000102C1865D

Habets, L. H., Deschildre, A., Knelissen, H., and Arrieta, J. (2000). "Zero effluent by application of biological treatment at high temperature," in Proc. Tappi 2000 Environment Conference (Denver, CO: Citeseer), 833-839.

Hamdan, N., Edward Kavazanjian, J., Rittmann, B. E., and Karatas, I. (2011). "Carbonate mineral precipitation for soil improvement through microbial denitrification," in Geo-Frontiers 2011, 3925-3934. doi:10.1061/41165(397)401

Hammes, F., Boon, N., De Villiers, J., Verstraete, W., and Siciliano, S. D. (2003). Strain-specific ureolytic microbial calcium carbonate precipitation. Appl. Environ. Microbiol. 69, 4901-4909. doi:10.1128/AEM.69.8.4901-4909.2003

Harkes, M. P., Van Paassen, L. A., Booster, J. L., Whiffin, V. S., and Van Loosdrecht, M. C. M. (2010). Fixation and distribution of bacterial activity in sand to induce carbonate precipitation for ground reinforcement. Ecol. Eng. 36, 112-117. doi:10.1016/j.ecoleng.2009.01.004

Hasan, H. (2000). Ureolytic microorganisms and soil fertility: a review. Commun. Soil Sci. Plant Anal. 31, 2565-2589. doi:10.1080/00103620009370609

Herrero, M., and Stuckey, D. (2014). Bioaugmentation and its application in wastewater treatment: a review. Chemosphere 140, 119-128. doi:10.1016/j. chemosphere.2014.10.033

Hinrichs, K.-U., Hayes, J. M., Sylva, S. P., Brewer, P. G., and Delong, E. F. (1999). Methane-consuming archaebacteria in marine sediments. Nature 398, 802-805. doi:10.1038/19751

Hodell, D. A., Schelske, C. L., Fahnenstiel, G. L., and Robbins, L. L. (1998). Biologically induced calcite and its isotopic composition in Lake Ontario. Limnol. Oceanogr. 43, 187-199. doi:10.4319/lo.1998.43.2.0187

Jiang, H.-B., Cheng, H.-M., Gao, K.-S., and Qiu, B.-S. (2013). Inactivation of Ca2+/ $\mathrm{H}+$ exchanger in Synechocystis sp strain PCC 6803 promotes cyanobacterial calcification by upregulating $\mathrm{CO}_{2}$-concentrating mechanisms. Appl. Environ. Microbiol. 79, 4048-4055. doi:10.1128/AEM.00681-13

Jimenez-Lopez, C., Rodriguez-Navarro, C., Pinar, G., Carrillo-Rosua, F. J., Rodriguez-Gallego, M., and Gonzalez-Munoz, M. T. (2007). Consolidation of degraded ornamental porous limestone stone by calcium carbonate precipitation induced by the microbiota inhabiting the stone. Chemosphere 68 , 1929-1936. doi:10.1016/j.chemosphere.2007.02.044

Johnston, M. D., Muench, B. A., Banks, E. D., and Barton, H. A. (2012). Human urine in Lechuguilla Cave: the microbiological impact and potential for bioremediation. J. Caves Karst Stud. 74, 278-291. doi:10.4311/2011MB0227

Jonkers, H. M., and Schlangen, E. (2009). A two component bacteria based self healing concrete. Concr. Repair Rehabil. Retrofit. 1, 119-120. doi:10.1201/9781439828403.ch27

Jonkers, H. M., Thijssen, A., Muyzer, G., Copuroglu, O., and Schlangen, E. (2010). Application of bacteria as self-healing agent for the development of sustainable concrete. Ecol. Eng. 36, 230-235. doi:10.1016/j.ecoleng.2008.12.036

Jørgensen, P. L., Tangney, M., Pedersen, P. E., Hastrup, S., Diderichsen, B., and Jørgensen, S. T. (2000). Cloning and sequencing of an alkaline protease gene from Bacillus lentus and amplification of the gene on the B. lentus chromosome by an improved technique. Appl. Environ. Microbiol. 66, 825-827. doi:10.1128/ AEM.66.2.825-827.2000
Jroundi, F., Fernandez-Vivas, A., Rodriguez-Navarro, C., Bedmar, E. J., and Gonzalez-Munoz, M. T. (2010). Bioconservation of deteriorated monumental calcarenite stone and identification of bacteria with carbonatogenic activity. Microb. Ecol. 60, 39-54. doi:10.1007/s00248-010-9665-y

Kang, C.-H., Han, S.-H., Shin, Y., Oh, S. J., and So, J.-S. (2014). Bioremediation of Cd by microbially induced calcite precipitation. Appl. Biochem. Biotechnol. 172, 2907-2915. doi:10.1007/s12010-014-0737-1

Karatas, I. (2008). Microbiological Improvement of the Physical Properties of Soils. Arizona: ProQuest.

Kfir, H., Rimbrot, S., and Markel, A. (2015). Toxic effects of hydrogen sulfide: experience with three simultaneous patients. QJM 108, 977-978. doi:10.1093/ qjmed/hcv108

Kim, J.-K., and Lee, C.-S. (1998). Prediction of differential drying shrinkage in concrete. Cem. Concr. Res. 28, 985-994. doi:10.1016/S0008-8846(98)00077-5

Kim, V. T., Muynck, W. D., Belie, N. D., and Verstraete, W. (2009). "Bacteria protect and heal concrete and stone," in WTA Schriftenreihe (Vol. 33). ed. L. Schueremans (Munich: International Association for Science and Technology of Building Maintenance and the Preservation of Monuments (WTA)), 439-457.

Knoll, A. H. (2003). Biomineralization and evolutionary history. Rev. Mineral. Geochem. 54, 329-356. doi:10.2113/0540329

Kosamu, I. B. M., and Obst, M. (2009). The influence of picocyanobacterial photosynthesis on calcite precipitation. Int. J. Environ. Sci. Technol. 6, 557-562. doi:10.1007/BF03326095

Kremer, B., Kazmierczak, J., and Stal, L. (2008). Calcium carbonate precipitation in cyanobacterial mats from sandy tidal flats of the North Sea. Geobiology 6 , 46-56. doi:10.1111/j.1472-4669.2007.00128.x

Krumbein, W., Paterson, D., and Zavarzin, G. (2003). Fossil and Recent Biofilms: A Natural History of the Impact of Life on Planet Earth. Dordrecht: Kluwer Scientific Publishers, 482.

Krumbein, W. E., and Giele, C. (1979). Calcification in a coccoid cyanobacterium associated with the formation of desert stromatolites. Sedimentology 26, 593-604. doi:10.1111/j.1365-3091.1979.tb00931.x

Kuhlmann, A. U., and Bremer, E. (2002). Osmotically regulated synthesis of the compatible solute ectoine in Bacillus pasteurii and related Bacillus spp. Appl. Environ. Microbiol. 68, 772-783. doi:10.1128/AEM.68.2.772-783.2002

Kumar, K., Dasgupta, C. N., Nayak, B., Lindblad, P., and Das, D. (2011). Development of suitable photobioreactors for $\mathrm{CO}_{2}$ sequestration addressing global warming using green algae and cyanobacteria. Bioresour. Technol. 102, 4945-4953. doi:10.1016/j.biortech.2011.01.054

Kumari, D., Li, M., Pan, X., and Xin-Yi, Q. (2014). Effect of bacterial treatment on Cr (VI) remediation from soil and subsequent plantation of Pisum sativum. Ecol. Eng. 73, 404-408. doi:10.1016/j.ecoleng.2014.09.093

Kurmaç, Y. (2009). The impact of toxicity of metals on the activity of ureolytic mixed culture during the precipitation of calcium. J. Hazard. Mater. 163, 1063-1067. doi:10.1016/j.jhazmat.2008.07.061

Last, F. M., Last, W. M., and Halden, N. M. (2010). Carbonate microbialites and hardgrounds from Manito Lake, an alkaline, hypersaline lake in the northern Great Plains of Canada. Sediment. Geol. 225, 34-49. doi:10.1016/j. sedgeo.2010.01.006

Lauchnor, E. G., Schultz, L. N., Bugni, S., Mitchell, A. C., Cunningham, A. B., and Gerlach, R. (2013). Bacterially induced calcium carbonate precipitation and strontium coprecipitation in a porous media flow system. Environ. Sci. Technol. 47, 1557-1564. doi:10.1021/es304240y

Lauritzen, S.-E., Ford, D. C., and Schwarcz, H. P. (1986). "Humic substances in speleothem matrix - paleoclimatic significance," in Proceedings of 9th International Congress of Speleology, Vol. 2 (Barcelona), 77-79.

Le Metayer-Levrel, G., Castanier, S., Orial, G., Loubiere, J. F., and Perthuisot, J. P. (1999). Applications of bacterial carbonatogenesis to the protection and regeneration of limestones in buildings and historic patrimony. Sediment. Geol. 126, 25-34. doi:10.1016/S0037-0738(99)00029-9

Léveillé, R., Longstaffe, F., and Fyfe, W. (2007). An isotopic and geochemical study of carbonate-clay mineralization in basaltic caves: abiotic versus microbial processes. Geobiology 5, 235-249. doi:10.1111/j.1472-4669.2007.00109.x

Liu, N., Aymonier, C., Lecoutre, C., Garrabos, Y., and Marre, S. (2012). Microfluidic approach for studying $\mathrm{CO}_{2}$ solubility in water and brine using confocal Raman spectroscopy. Chem. Phys. Lett. 551, 139-143. doi:10.1016/j.cplett.2012.09.007

Liu, Q., Wang, H., Zhao, R., Qiu, X., and Gong, L. (2010). Bacteria isolated from dripping water in the oligotrophic Heshang cave in central China. J. Earth Sci. 21, 325-328. doi:10.1007/s12583-010-0250-6 
López-García, P., Kazmierczak, J., Benzerara, K., Kempe, S., Guyot, F., and Moreira, D. (2005). Bacterial diversity and carbonate precipitation in the giant microbialites from the highly alkaline Lake Van, Turkey. Extremophiles 9, 263-274. doi:10.1007/s00792-005-0457-0

Ludwig, R., Al-Horani, F. A., De Beer, D., and Jonkers, H. M. (2005). Photosynthesiscontrolled calcification in a hypersaline microbial mat. Limnol. Oceanogr. 50, 1836-1843. doi:10.4319/lo.2005.50.6.1836

Mahanty, B., Kim, S., and Kim, C. G. (2013). Assessment of a biostimulated or bioaugmented calcification system with Bacillus pasteurii in a simulated soil environment. Microb. Ecol. 65, 679-688. doi:10.1007/s00248-012-0137-4

Maignien, L., Depreiter, D., Foubert, A., Reveillaud, J., De Mol, L., Boeckx, P., et al. (2011). Anaerobic oxidation of methane in a cold-water coral carbonate mound from the Gulf of Cadiz. Int. J. Earth Sci. 100, 1413-1422. doi:10.1007/ s00531-010-0528-Z

Martin, D., Dodds, K., Butler, I. B., and Ngwenya, B. T. (2013). Carbonate precipitation under pressure for bioengineering in the anaerobic subsurface via denitrification. Environ. Sci. Technol. 47, 8692-8699. doi:10.1021/ es401270q

Martin, D., Dodds, K., Ngwenya, B. T., Butler, I. B., and Elphick, S. C. (2012). Inhibition of Sporosarcina pasteurii under anoxic conditions: implications for subsurface carbonate precipitation and remediation via ureolysis. Environ. Sci. Technol. 46, 8351-8355. doi:10.1021/es3015875

Martín, H. G., and Goldenfeld, N. (2006). Estimation of microbial cover distributions at Mammoth hot Springs using a multiple clone library resampling method. Environ. Microbiol. 8, 1145-1154. doi:10.1111/j.1462-2920.2006.01003.x

Martinez, B., Dejong, J., Ginn, T., Montoya, B., Barkouki, T., Hunt, C., et al. (2013). Experimental optimization of microbial-induced carbonate precipitation for soil improvement. J. Geotech. Geoenviron. Eng. 139, 587-598. doi:10.1061/ (ASCE)GT.1943-5606.0000787

May, E. (2005). Biobrush Research Monograph: Novel Approaches to Conserve Our European Heritage. EVK4-CT-2001-00055.

McCutcheon, J., Power, I. M., Harrison, A. L., Dipple, G. M., and Southam, G. (2014). A greenhouse-scale photosynthetic microbial bioreactor for carbon sequestration in magnesium carbonate minerals. Environ. Sci. Technol. 48, 9142-9151. doi:10.1021/es500344s

Merz-Preiß, M., and Riding, R. (1999). Cyanobacterial tufa calcification in two freshwater streams: ambient environment, chemical thresholds and biological processes. Sediment. Geol. 126, 103-124. doi:10.1016/ S0037-0738(99)00035-4

Meyer, F., Bang, S., Min, S., Stetler, L., and Bang, S. (2011). MicrobiologicallyInduced Soil Stabilization: Application of Sporosarcina pasteurii for Fugitive Dust Control. Geo-Frontiers 2011, 4002-4011. doi:10.1061/41165(397)409

Miller, A. G., and Colman, B. (1980). Evidence for HCO3- transport by the blue-green alga (cyanobacterium) Coccochloris peniocystis. Plant Physiol. 65, 397-402. doi:10.1104/pp.65.2.397

Mitchell, A. C., Dideriksen, K., Spangler, L. H., Cunningham, A. B., and Gerlach, R. (2010). Microbially enhanced carbon capture and storage by mineral-trapping and solubility-trapping. Environ. Sci. Technol. 44, 5270-5276. doi:10.1021/ es903270w

Mitchell, A. C., Phillips, A., Schultz, L., Parks, S., Spangler, L., Cunningham, A. B., et al. (2013). Microbial $\mathrm{CaCO}_{3}$ mineral formation and stability in an experimentally simulated high pressure saline aquifer with supercritical $\mathrm{CO}_{2}$. Int. J. Greenhouse Gas Control 15, 86-96. doi:10.1016/j.ijggc.2013.02.001

Mitchell, A. C., Phillips, A. J., Hamilton, M. A., Gerlach, R., Hollis, W. K., Kaszuba, J. P., et al. (2008). Resilience of planktonic and biofilm cultures to supercritical $\mathrm{CO}_{2}$. J. Supercrit. Fluids 47, 318-325. doi:10.1016/j.supflu.2008.07.005

Mitchell, A. C., Phillips, A. J., Hiebert, R., Gerlach, R., Spangler, L. H., and Cunningham, A. B. (2009). Biofilm enhanced geologic sequestration of supercritical $\mathrm{CO}_{2}$. Int. J. Greenhouse Gas Control 3, 90-99. doi:10.1016/j. ijggc.2008.05.002

Mobley, H., Island, M. D., and Hausinger, R. P. (1995). Molecular biology of microbial ureases. Microbiol. Rev. 59, 451-480.

Mobley, H. L., and Hausinger, R. P. (1989). Microbial ureases: significance, regulation, and molecular characterization. Microbiol. Rev. 53, 85-108.

Montoya, B., Dejong, J., and Boulanger, R. (2013). Dynamic response of liquefiable sand improved by microbial-induced calcite precipitation. Géotechnique 63, 302-312. doi:10.1680/geot.SIP13.P.019
Müller, N., and Harnisch, J. (2008). A Blueprint for a Climate Friendly Cement Industry. Report for the WWF-Lafarge Conservation Partnership. Gland: WWF.

Neu, T. R. (1996). Significance of bacterial surface-active compounds in interaction of bacteria with interfaces. Microbiol. Rev. 60, 151.

Obst, M., Dynes, J., Lawrence, J., Swerhone, G., Benzerara, K., Karunakaran, C., et al. (2009). Precipitation of amorphous $\mathrm{CaCO}_{3}$ (aragonite-like) by cyanobacteria: a STXM study of the influence of EPS on the nucleation process. Geochim. Cosmochim. Acta 73, 4180-4198. doi:10.1016/j.gca.2009.04.013

Okumura, T., Takashima, C., and Kano, A. (2013). Textures and processes of laminated travertines formed by unicellular cyanobacteria in Myoken hot spring, Southwestern Japan. Isl. Arc 22, 410-426. doi:10.1111/iar.12034

Okyay, T. O., and Rodrigues, D. F. (2015). Biotic and abiotic effects on $\mathrm{CO}_{2}$ sequestration during microbially-induced calcium carbonate precipitation. FEMS Microbiol. Ecol. 91, fiv017. doi:10.1093/femsec/fiv017

Omar, N. B., Martínez-Cañamero, M., González-Muñoz, M. T., Arias, J. M., and Huertas, F. (1995). Myxococcus xanthus' killed cells as inducers of struvite crystallization. Its possible role in the biomineralization processes. Chemosphere 30, 2387-2396. doi:10.1016/0045-6535(95)00110-T

Ortiz, M., Neilson, J. W., Nelson, W. M., Legatzki, A., Byrne, A., Yu, Y., et al. (2013). Profiling bacterial diversity and taxonomic composition on speleothem surfaces in Kartchner Caverns, AZ. Microb. Ecol. 65, 371-383. doi:10.1007/ s00248-012-0143-6

Pedley, H. (1990). Classification and environmental models of cool freshwater tufas. Sediment. Geol. 68, 143-154. doi:10.1016/0037-0738(90)90124-C

Pedley, M. (2009). Tufas and travertines of the Mediterranean region: a testing ground for freshwater carbonate concepts and developments. Sedimentology 56, 221-246. doi:10.1111/j.1365-3091.2008.01012.x

Pentecost, A. (2003). Cyanobacteria associated with hot spring travertines. Can. J. Earth Sci. 40, 1447-1457. doi:10.1139/e03-075

Perito, B., Marvasi, M., Barabesi, C., Mastromei, G., Bracci, S., Vendrell, M., et al. (2014). A Bacillus subtilis cell fraction (BCF) inducing calcium carbonate precipitation: biotechnological perspectives for monumental stone reinforcement. J. Cult. Heritage 15, 345-351. doi:10.1016/j.culher.2013.10.001

Persson, B. (1997). Self-desiccation and its importance in concrete technology. Mater. Struct. 30, 293-305. doi:10.1007/BF02486354

Phillips, A. J., Gerlach, R., Lauchnor, E., Mitchell, A. C., Cunningham, A. B., and Spangler, L. (2013). Engineered applications of ureolytic biomineralization: a review. Biofouling 29, 715-733. doi:10.1080/08927014.2013.796550

Phillips, A. J., Lauchnor, E., Eldring, J., Esposito, R., Mitchell, A. C., Gerlach, R., et al. (2012). Potential $\mathrm{CO}_{2}$ leakage reduction through biofilm-induced calcium carbonate precipitation. Environ. Sci. Technol. 47, 142-149. doi:10.1021/ es301294q

Planavsky, N., Reid, R., Lyons, T., Myshrall, K., and Visscher, P. (2009). Formation and diagenesis of modern marine calcified cyanobacteria. Geobiology 7, 566-576. doi:10.1111/j.1472-4669.2009.00216.x

Plée, K., Pacton, M., and Ariztegui, D. (2010). Discriminating the role of photosynthetic and heterotrophic microbes triggering low-Mg calcite precipitation in freshwater biofilms (Lake Geneva, Switzerland). Geomicrobiol. J. 27, 391-399. doi:10.1080/01490450903451526

Power, I. M., Wilson, S. A., Small, D. P., Dipple, G. M., Wan, W. K., and Southam, G. (2011). Microbially mediated mineral carbonation: roles of phototrophy and heterotrophy. Environ. Sci. Technol. 45, 9061-9068. doi:10.1021/es201648g

Proom, H., and Knight, B. (1955). The minimal nutritional requirements of some species in the genus Bacillus. J. Gen. Microbiol. 13, 474-480. doi:10.1099/00221287-13-3-474

Qian, C., Pan, Q., and Wang, R. (2010). Cementation of sand grains based on carbonate precipitation induced by microorganism. Sci. China Technol. Sci. 53, 2198-2206. doi:10.1007/s11431-009-3189-z

Ramachandran, S. K., Ramakrishnan, V., and Bang, S. S. (2001). Remediation of concrete using micro-organisms. ACI Mater. J. 98, 3-9.

Ramakrishnan, V. (2007). "Performance characteristics of bacterial concrete-a smart biomaterial", in Proceedings of the First International Conference on Recent Advances in Concrete Technology. (Destech Publications, Inc.), 67-78.

Ramakrishnan, V., Bang, S., and Deo, K. (1998). "A novel technique for repairing cracks in high performance concrete using bacteria," in Proc. of the Int. Conf. on HPHSC (Perth), 597-618. 
Ramanan, R., Kannan, K., Deshkar, A., Yadav, R., and Chakrabarti, T. (2010). Enhanced algal $\mathrm{CO}_{2}$ sequestration through calcite deposition by Chlorella sp. and Spirulina platensis in a mini-raceway pond. Bioresour. Technol. 101, 2616-2622. doi:10.1016/j.biortech.2009.10.061

Reeburgh, W. S. (2007). Oceanic methane biogeochemistry. Chem. Rev. 107, 486-513. doi: $10.1021 / \mathrm{cr} 050362 \mathrm{v}$

Reeder, R. J., Lamble, G. M., and Northrup, P. A. (1999). XAFS study of the coordination and local relaxation around $\mathrm{Co}^{\wedge} 2^{\wedge}+, \mathrm{Zn}^{\wedge} 2^{\wedge}+, \mathrm{Pb}^{\wedge} 2^{\wedge}+$, and $\mathrm{Ba}^{\wedge}$ $2^{\wedge}+$, trace elements in calcite. Am. Mineral. 84, 1049-1060.

Reid, R. P., Visscher, P. T., Decho, A. W., Stolz, J. F., Bebout, B., Dupraz, C., et al. (2000). The role of microbes in accretion, lamination and early lithification of modern marine stromatolites. Nature 406, 989-992. doi:10.1038/35023158

Riding, R. (2000). Microbial carbonates: the geological record of calcified bacterial-algal mats and biofilms. Sedimentology 47, 179-214. doi:10.1046/j.1365-3091.2000.00003.x

Riding, R., and Liang, L. (2005). Geobiology of microbial carbonates: metazoan and seawater saturation state influences on secular trends during the Phanerozoic. Palaeogeogr. Palaeoclimatol. Palaeoecol. 219, 101-115. doi:10.1016/j. palaeo.2004.11.018

Rodriguez-Martinez, M., Sanchez, F., Walliser, E. O., and Reitner, J. (2012). An upper Turonian fine-grained shallow marine stromatolite bed from the munecas formation, northern Iberian ranges, Spain. Sediment. Geol. 263, 96-108. doi:10.1016/j.sedgeo.2011.06.014

Rodriguez-Navarro, C., Rodriguez-Gallego, M., Ben Chekroun, K., and GonzalezMunoz, M. T. (2003). Conservation of ornamental stone by Myxococcus xanthus-induced carbonate biomineralization. Appl. Environ. Microbiol. 69, 2182-2193. doi:10.1128/AEM.69.4.2182-2193.2003

Rossi, F., Olguín, E. J., Diels, L., and De Philippis, R. (2015). Microbial fixation of $\mathrm{CO}_{2}$ in water bodies and in drylands to combat climate change, soil loss and desertification. N Biotechnol. 32, 109-120. doi:10.1016/j.nbt.2013.12.002

Rubio, F. C., Camacho, F. G., Sevilla, J., Chisti, Y., and Grima, E. M. (2003). A mechanistic model of photosynthesis in microalgae. Biotechnol. Bioeng. 81, 459-473. doi:10.1002/bit.10492

Sarayu, K., Iyer, N. R., and Murthy, A. R. (2014). Exploration on the biotechnological aspect of the ureolytic bacteria for the production of the cementitious materials - a review. Appl. Biochem. Biotechnol. 172, 2308-2323. doi:10.1007/ s12010-013-0686-0

Sari, Y. D. (2015). Soil strength improvement by microbial cementation. Mar. Georesour. Geotechnol. 33, 567-571. doi:10.1080/1064119X.2014.953234

Schoon, R., Bissett, A., and Beer, D. D. (2010). Resilience of pore-water chemistry and calcification in photosynthetic zones of calcifying sediments. Limnol. Oceanogr. 55, 377-385. doi:10.4319/lo.2010.55.1.0377

Schrag, D. P. (2007). Preparing to capture carbon. Science 315, 812-813. doi:10.1126/ science. 1137632

Sel, I., Ozhan, H. B., Cibik, R., and Buyukcangaz, E. (2015). Bacteria-induced cementation process in loose sand medium. Mar. Georesour. Geotechnol. 33, 403-407. doi:10.1080/1064119X.2014.909912

Sen, R. (2008). Biotechnology in petroleum recovery: the microbial EOR. Prog. Energy Combust. Sci. 34, 714-724. doi:10.1016/j.pecs.2008.05.001

Shirakawa, M., John, V., De Belie, N., Alves, J., Pinto, J., and Gaylarde, C. (2015). Susceptibility of biocalcite-modified fiber cement to biodeterioration. Int. Biodeterior. Biodegradation 103, 215-220. doi:10.1016/j. ibiod.2015.04.003

Shirakawa, M. A., Werle, A. P., Gaylarde, C. C., Loh, K., and John, V. M. (2014). Fungal and phototroph growth on fiber cement roofs and its influence on solar reflectance in a tropical climate. Int. Biodeterior. Biodegradation 95, 332-337. doi:10.1016/j.ibiod.2013.12.003

Siefert, J. L., Larios-Sanz, M., Nakamura, L. K., Slepecky, R. A., Paul, J. H., Moore, E. R., et al. (2000). Phylogeny of marine Bacillus isolates from the Gulf of Mexico. Curr. Microbiol. 41, 84-88. doi:10.1007/s002840010098

Silva, F. B., Boon, N., De Belie, N., and Verstraete, W. (2015). Industrial application of biological self-healing concrete: challenges and economical feasibility. J. Commer. Biotechnol. 21, 31-38. doi:10.5912/jcb662

Suthar, H., Hingurao, K., Desai, A., and Nerurkar, A. (2009). Selective plugging strategy-based microbial-enhanced oil recovery using Bacillus licheniformis TT33. J. Microbiol. Biotechnol. 19, 1230-1237. doi:10.4014/jmb.0904.04043

Tekin, E., Kayabali, K., Ayyidiz, T., and Ileri, O. (2000). Evidence of microbiologic activity in modern travertines: sicakcermik geothermal field, central Turkey. Carbonates Evaporites 15, 18-27. doi:10.1007/BF03175645
Thompson, J. B., Schultze-Lam, S., Beveridge, T. J., and Des Marais, D. J. (1997). Whiting events: biogenic origin due to the photosynthetic activity of cyanobacterial picoplankton. Limnol. Oceanogr. 42, 133-141. doi:10.4319/ lo.1997.42.1.0133

Tiano, P., Biagiotti, L., and Mastromei, G. (1999). Bacterial bio-mediated calcite precipitation for monumental stones conservation: methods of evaluation. J. Microbiol. Methods 36, 139-145. doi:10.1016/S0167-7012(99)00019-6

Tiano, P., and Cantisani, E. (2005). Precipitazione bioindotta di calcite per la conservazione delle pietre monumentali: bioreinforce project. Arkos $6,50-56$.

Tourney, J., and Ngwenya, B. T. (2009). Bacterial extracellular polymeric substances (EPS) mediate $\mathrm{CaCO}_{3}$ morphology and polymorphism. Chem. Geol. 262, 138-146. doi:10.1016/j.chemgeo.2009.01.006

Tourney, J., and Ngwenya, B. T. (2014). The role of bacterial extracellular polymeric substances in geomicrobiology. Chem. Geol. 386, 115-132. doi:10.1016/j. chemgeo.2014.08.011

Tourney, J., Ngwenya, B. T., Mosselmans, J. F., Tetley, L., and Cowie, G. L. (2008). The effect of extracellular polymers (EPS) on the proton adsorption characteristics of the thermophile Bacillus licheniformis S-86. Chem. Geol. 247, 1-15. doi:10.1016/j.chemgeo.2007.09.012

Tsuneda, S., Aikawa, H., Hayashi, H., Yuasa, A., and Hirata, A. (2003). Extracellular polymeric substances responsible for bacterial adhesion onto solid surface. FEMS Microbiol. Lett. 223, 287-292. doi:10.1016/S0378-1097(03)00399-9

Van Loosdrecht, M. C., Lyklema, J., Norde, W., and Zehnder, A. J. (1989). Bacterial adhesion: a physicochemical approach. Microb. Ecol. 17, 1-15. doi:10.1007/ BF02025589

Van Paassen, L. A., Daza, C. M., Staal, M., Sorokin, D. Y., Van Der Zon, W., and Van Loosdrecht, M. C. (2010). Potential soil reinforcement by biological denitrification. Ecol. Eng. 36, 168-175. doi:10.1016/j.ecoleng.2009.03.026

Vasconcelos, C., Dittrich, M., and McKenzie, J. A. (2014). Evidence of microbiocoenosis in the formation of laminae in modern stromatolites. Facies 60, 3-13. doi:10.1007/s10347-013-0371-3

Visscher, P. T., Reid, R. P., and Bebout, B. M. (2000). Microscale observations of sulfate reduction: correlation of microbial activity with lithified micritic laminae in modern marine stromatolites. Geology 28, 919-922. doi:10.1130/0091-7613 (2000)28<919:MOOSRC>2.0.CO;2

Waditee, R., Hossain, G. S., Tanaka, Y., Nakamura, T., Shikata, M., Takano, J., et al. (2004). Isolation and functional characterization of $\mathrm{Ca} 2+/ \mathrm{H}+$ antiporters from cyanobacteria. J. Biol. Chem. 279, 4330-4338. doi:10.1074/jbc.M310282200

Wang, J. Y., Van Tittelboom, K., De Belie, N., and Verstraete, W. (2012). Use of silica gel or polyurethane immobilized bacteria for self-healing concrete. Constr. Build. Mater. 26, 532-540. doi:10.1016/j.conbuildmat.2011.06.054

Wang, X., Feng, Y., Liu, J., Lee, H., Li, C., Li, N., et al. (2010). Sequestration of $\mathrm{CO}_{2}$ discharged from anode by algal cathode in microbial carbon capture cells (MCCs). Biosens. Bioelectron. 25, 2639-2643. doi:10.1016/j.bios.2010.04.036

Warren, L. A., Maurice, P. A., Parmar, N., and Ferris, F. G. (2001). Microbially mediated calcium carbonate precipitation: implications for interpreting calcite precipitation and for solid-phase capture of inorganic contaminants. Geomicrobiol. J. 18, 93-115. doi:10.1080/01490450151079833

Webb, G. E. (2001). "Biologically induced carbonate precipitation in reefs through time," in The History and Sedimentology of Ancient Reef Systems. ed. G. D. Jr. Stanley (New York: Springer), 159-203. doi:10.1007/978-1-4615-1219-6_5

Wei, S., Cui, H., Jiang, Z., Liu, H., He, H., and Fang, N. (2015). Biomineralization processes of calcite induced by bacteria isolated from marine sediments. Braz. J. Microbiol. 46, 455-464. doi:10.1590/S1517-838246220140533

Whiffin, V. S., Van Paassen, L. A., and Harkes, M. P. (2007). Microbial carbonate precipitation as a soil improvement technique. Geomicrobiol. J. 24, 417-423. doi:10.1080/01490450701436505

Wong, L. S. (2015). Microbial cementation of ureolytic bacteria from the genus Bacillus: a review of the bacterial application on cement-based materials for cleaner production. J. Clean. Prod. 93, 5-17. doi:10.1016/j.jclepro.2015.01.019

Wright, V. P. (1989). Terrestrial stromatolites and laminar calcretes: a review. Sediment. Geol. 65, 1-13. doi:10.1016/0037-0738(89)90002-X

Yee, N., Fein, J. B., and Daughney, C. J. (2000). Experimental study of the pH, ionic strength, and reversibility behavior of bacteria-mineral adsorption. Geochim. Cosmochim. Acta 64, 609-617. doi:10.1016/S0016-7037(99)00342-7

Yoshida, N., Higashimura, E., and Saeki, Y. (2010). Catalytic biomineralization of fluorescent calcite by the thermophilic bacterium Geobacillus thermoglucosidasius. Appl. Environ. Microbiol. 76, 7322-7327. doi:10.1128/AEM.01767-10 
Zamarreno, D. V., Inkpen, R., and May, E. (2009). Carbonate crystals precipitated by freshwater bacteria and their use as a limestone consolidant. Appl. Environ. Microbiol. 75, 5981-5990. doi:10.1128/AEM.02079-08

Zhang, J., Burrows, S., Gleason, C., Matthews, M. A., Drews, M. J., Laberge, M., et al. (2006). Sterilizing Bacillus pumilus spores using supercritical carbon dioxide. J. Microbiol. Methods 66, 479-485. doi:10.1016/j. mimet.2006.01.012

Zhu, T., Paulo, C., Merroun, M. L., and Dittrich, M. (2015). Potential application of biomineralization by Synechococcus PCC8806 for concrete restoration. Ecol. Eng. 82, 459-468. doi:10.1016/j.ecoleng.2015.05.017
Conflict of Interest Statement: The authors declare that the research was conducted in the absence of any commercial or financial relationships that could be construed as a potential conflict of interest.

Copyright $\odot 2016 \mathrm{Zhu}$ and Dittrich. This is an open-access article distributed under the terms of the Creative Commons Attribution License (CC BY). The use, distribution or reproduction in other forums is permitted, provided the original author(s) or licensor are credited and that the original publication in this journal is cited, in accordance with accepted academic practice. No use, distribution or reproduction is permitted which does not comply with these terms. 